\title{
Relationship between Risk-taking, Capital Regulation and Bank Performance: Empirical Evidence from Bangladesh
}

\author{
Morshedur M. RAHMAN ${ }^{*}$, Ali Arshad CHOWDHURY ${ }^{* *}$, Mouri DEY ${ }^{* * *}$
}

Received: April 19, 2018

Revised: October 14, 2018 Accepted: November 4, 2018.

\begin{abstract}
This paper attempts to analyse the relationships between risk-taking, capital regulation and performance in banking sector of Bangladesh. We use Generalized Methods of Moments (GMM) in an unbalanced panel data using 38 commercial banks of Bangladesh for a period of 2007-2016. The empirical results show a significant negative relation between risk taking and capital regulation. Results also reveal that there is a significant positive relation between capital regulation and performance, and a significant negative relation between risk and performance. This study provides various suggestions about risk management and capital adequacy for the regulators, stakeholders and government.
\end{abstract}

Keywords: capital regulation; risk-taking; commercial banks, panel data analysis; performance.

JEL Code Classification: C3, C33, G21, G32, G28

UDC: 336.71

DOI: https://doi.org/10.17015/ejbe.2018.022.02.

\footnotetext{
* Department of Accounting, University of Chittagong, Chittagong, Bangladesh. E-mail: mmrais@cu.ac.bd. ** Department of Accounting, University of Chittagong, Chittagong, Bangladesh.E-mail: arshad@cu.ac.bd.

*** Department of Accounting, University of Chittagong, Chittagong, Bangladesh. E-mail: $\underline{\text { mouridey@cu.ac.bd }}$ 


\section{Introduction}

Stable position in the international banking system was urgently warranted. To this end Basel Accord was adopted firstly in 1988. Later Basel II was introduced as Basel I was not sufficient to measure risk exposures. Due to global financial crisis in the 2007-2009, the regulatory capital and liquidity failed. For the remedies a new Basel Accord (Basel III) was introduced in 2010. Establishment of the minimum regulatory capital and liquidity that are required by the banks for absorbing unexpected losses is the main objective of the Basel III (Eubanks, 2010; Tsai \& Hung, 2013). According to Basel III capital standard and buffer, banks need to have more capital as well as a better quality of capital (Lee \& Hsieh, 2013).

Due to financial crisis, regulatory capital requirements were supposed to ensure the solvency of banks. The minimum capital requirements on banks were set out by the regulator in line with Basel guidelines to reduce banks' risk. The regulator confirms the minimum capital requirement by imposing a number of penalties for the non-compliance with the requirements. The regulator in individual country sets the instruments to do it in accordance with the requirements of the country. The nature of penalties may be implicit, explicit or both. With the incentives from the regulator, banks set their capital optimally. The actual capital is always differing from the regulatory minimum and the one that would result if there is no regulation. It is expected that banks have to maintain more capital known as buffer than the minimum capital requirement for avoiding the risk of penalty from regulator.

One of the most important aspects of banking regulation is capital regulation. Bank capital has two functions, (i) investment function and (ii) insurance function. These functions have significant impact on banks' stability, liquidity and soundness (Scannella, 2012). For example, if a bank does not have adequate capital to offset risk exposure then the bank will increase the premium of risk to be paid to bank liabilities subscribers. There will be a negative effect to the economic performance. Capital requirement has impact on many banking activities, for example (i) strategic decision making, (ii) growth in banking industry, (iii) competitiveness, (iv) portfolio risks, (v) investments' risk profiles, (vi) expected performance, and (vii) structure of liabilities and assets.

It has been debating on the opportunities and effectiveness of capital regulation and its relation with portfolios of investment since the 1988 Basel I Capital Accord. The increment in capital ratios (shareholders' equity to total assets) may increase the riskier assets by the banks (Kahane, 1977; Kim \& Santomero, 1988). By increasing risk exposure banks may respond to regulatory capital (Scannella, 2012). There is a possibility to select a portfolio having higher return as well as higher risk.

Basel II which was already adopted in the Europe and many banks in Europe have now reported their regulatory capital in accordance with the new capital accord (BASEL III). Many countries in Asia also have implemented Basel II. For example, in 
Singapore it was implemented in 2008, India has implemented in 2009, and Bangladesh has implemented in 2010. As the change in capital may positively or adversely affect the risk and performance, the relationship among the regulatory capital, risk and performance has become a cause for concern ( Lee \& Hsieh, 2013). But, empirical study on this area is limited especially in Asia. Barth, Caprio, and Levine (2008) found that some countries in Asia, like Singapore, Philippines, are increasing their capital requirements. On the other hand, some other countries, like Japan and South Korea, are making their capital requirement easier after their crisis. On the contrary, Singapore, Thailand, Malaysia and South Korea provided supervisor with more power. Barth, Caprio, and Levine (2005) found that the power of supervisor is not helpful in banks' stability and performance. By intensifying the restrictions of regulators, some countries in Asia have augmented banking system fragility.

Therefore there is an option to investigate the banking industry of Asia. In this direction, we want to give some important light on the factors of risk-taking by banks in Bangladesh and examine its relationship with performance and regulatory capital. Until now, there are very few papers that consider three variables (risk, regulatory capital and performance). Likewise, no study has yet done on the relationship among risk, regulatory capital and performance for the Bangladesh banking system. To our knowledge, this is the first study on relationships among risk-taking, regulatory capital and performance in the banking sector of Bangladesh.

This attempt supposed to contribute to the literature in many ways. First, in the comparison with the previous studies that focus on European or US banking sector as well as some studies on Asia, it is the first empirical study on Bangladesh. Second, the study considers the latest banking data from a period of 2007-2016 which focuses on the last banking reform in Bangladesh in 2009. Third, previous studies mainly focus on the relationship between risk and capital and very few of them have focused on the relationship between capital and performance. This study considers three variables (risk, regulatory capital and performance) simultaneously. Fourth, in this paper we consider three alternative measures for risk which is the highest in the literature. We use some new variables (internal control variables and macroeconomic variables) as control variables that were not used earlier.

As per our knowledge goes, this is the first study that examines the empirical relationship among risk, regulatory capital and performance of banks in Bangladesh. For this purpose, we use data from 38 commercial banks from Bangladesh covering the period 2007-2016. We apply GMM technique developed by Arellano and Bover (1995) and Blundell and Bond (2000) to an unbalanced panel of commercial banks to account for potential both endogeneity and serial correlation problems. 
The remainder of the paper is structured as follows. Section 2 summarizes the previous literature. Section 3 describes the data, variables used in the study. Section 4 attempts to outline the econometric model to assess the relationship between the risk-taking, capital regulation and performance. Section 5 reports empirical results. In section 6, we present concluding remarks and recommendations.

\section{Literature Review and Hypotheses}

In the context of literature survey, the selected previous literatures have been divided into three groups. First section deals with literature on relationship between risk and capital regulation. Second section focuses on the literature on the relationship between capital regulation and performance. Third section highlights the literature on the relationship between risk and performance.

\subsection{Relationship between capital regulation and risk}

The regulatory capital requirements limit the banks' risk taking to protect banks from risk of insolvency (Homölle, 2004). In the context of the implications of regulatory policies from the regulator, examination of the relationship between capital regulation and risk is considered to be one of the important issues today (Lee \& Hsieh, 2013). A comprehensive literature survey on the relationship between risk and capital regulation is provided in Table 1. From the literature it is seen that most of the studies are done on banks of developed countries. Very few studies are done on Asian countries and there is no study on a least developed country like Bangladesh. In this paper, we focus on banks from Bangladesh by using the GMM technique.

It is assumed that higher capital requirements will have a positive impact on risk of the banking sector (Lee \& Chih, 2013), but empirical results are mixed. Some studies show that there is a positive relationship between risk and capital (Altunbas, Carbo, Gardener, \& Molyneux, 2007; Blum, 1999; Kahane, 1977; Kim \& Santomero, 1988; Koehn \& Santomero, 1980; Laeven \& Levine, 2009; Lin, Penm, Gong, \& Chang, 2005; Rime, 2001; Shrieves \& Dahl, 1992). On the other hand, some studies find a negative relationship between risk and capital (Agoraki, Delis, \& Pasiouras, 2011; Ho \& Hsu, 2010; Jacques \& Nigro, 1997; Lee \& Hsieh, 2013; T.-H. Lee \& Chih, 2013; Zhang, Wu, \& Liu, 2008).

Mixed results are found in some studies, for example: Calem and Rob (1999), Iwatsubo (2007). No relation is also found in some studies, for example: Aggarwal and Jacques (2001), Hussain and Hassan (2005), Guidara, Lai, Soumaré, and Tchana (2013). By using a mean-variance approach, Kahane (1977), Koehn and Santomero (1980), Kim and Santomero (1988) show that single capital ratio regulation is not enough to control risk. For ignoring the option value of deposit insurance, the mean-variance is not appropriate (Furlong \& Keeley, 1989; Keeley \& Furlong, 1990). 
Relationship between Risk-taking, Capital Regulation and Bank Performance: Empirical ...

Table 1. Literature on the Relationship between risk and capital regulation

\begin{tabular}{|c|c|c|c|}
\hline Authors & $\begin{array}{l}\text { Country and } \\
\text { periods }\end{array}$ & $\begin{array}{l}\text { Methods } \\
\text { used }\end{array}$ & Results \\
\hline Kahane (1977) & - & $\begin{array}{l}\text { Portfolio } \\
\text { Theory }\end{array}$ & $\begin{array}{l}\text { Only capital ratio regulation does not prevent } \\
\text { banks seeking high risk. }\end{array}$ \\
\hline $\begin{array}{l}\text { Koehn and } \\
\text { Santomero } \\
(1980)\end{array}$ & - & $\begin{array}{l}\text { Portfolio } \\
\text { Theory }\end{array}$ & $\begin{array}{l}\text { Capital regulation is not an effective regulatory } \\
\text { tool. It should regulate capital ratios and capital } \\
\text { composition and will allow the probability of } \\
\text { failure of risk to increase. }\end{array}$ \\
\hline $\begin{array}{l}\text { Kim and } \\
\text { Santomero } \\
(1988)\end{array}$ & - & $\begin{array}{l}\text { Portfolio } \\
\text { Theory }\end{array}$ & $\begin{array}{l}\text { Single capital ratio regulation cannot lower the } \\
\text { probability of failure. Risk guiding capital regulation } \\
\text { is an effective tool. }\end{array}$ \\
\hline $\begin{array}{l}\text { Shrieves and } \\
\text { Dahl (1992) }\end{array}$ & $\begin{array}{l}\text { US } \\
1983-1987\end{array}$ & $3 S L S$ & $\begin{array}{l}\text { There is a positive association between changes in } \\
\text { risk and changes in capital. }\end{array}$ \\
\hline $\begin{array}{l}\text { Jacques and } \\
\text { Nigro (1997) }\end{array}$ & $\begin{array}{l}\text { US } \\
1990-1991\end{array}$ & $3 S L S$ & $\begin{array}{l}\text { The risk-based capital standards are effective in } \\
\text { increasing capital ratios and reducing portfolio risk } \\
\text { in commercial banks i.e. there is a negative } \\
\text { relationship between capital standard and risk. }\end{array}$ \\
\hline Calem (1999) & $\begin{array}{l}\text { US } \\
1984-1993\end{array}$ & - & $\begin{array}{l}\text { The relationship between capital and risk-taking is } \\
\text { U-shaped as a bank increases capital, it first takes } \\
\text { less risk. For a deposit insurance premium option } \\
\text { for undercapitalized banks, the banks are induced } \\
\text { to take more risk. }\end{array}$ \\
\hline Blum (1999) & - & - & $\begin{array}{l}\text { If the cost is excessive to raise equity, the } \\
\text { possibility to increase equity tomorrow is to } \\
\text { increase risk today. }\end{array}$ \\
\hline $\begin{array}{l}\text { Aggarwal and } \\
\text { Jacques (2001) }\end{array}$ & $\begin{array}{l}\text { US } \\
1991-1996 \\
\end{array}$ & $3 S L S$ & $\begin{array}{l}\text { Without offsetting increases in credit risk US banks } \\
\text { increase their capital ratios. }\end{array}$ \\
\hline Rime (2001) & $\begin{array}{l}\text { Swiss Bank } \\
1989-1995\end{array}$ & $3 S L S$ & $\begin{array}{l}\text { The association between the changes in risk and } \\
\text { the changes in capital is positive. }\end{array}$ \\
\hline $\begin{array}{l}\text { Hussain and } \\
\text { Hassan (2005) }\end{array}$ & $\begin{array}{l}\text { Developing } \\
\text { Countries } \\
1991-2006\end{array}$ & - & $\begin{array}{l}\text { Regulations reduce portfolio risk of banks. For } \\
\text { designing and implementing regulatory policies } \\
\text { special attention should be given to the business, } \\
\text { environmental, legal, cultural realities of } \\
\text { developing countries. }\end{array}$ \\
\hline Lin et al. (2005) & $\begin{array}{l}\text { Taiwan } \\
\text { 1993-2000 }\end{array}$ & OLS & $\begin{array}{l}\text { Positive relationship is found between capital } \\
\text { adequacy and risk. }\end{array}$ \\
\hline Iwatsubo (2007) & $\begin{array}{l}\text { Japan } \\
1990-2000\end{array}$ & - & $\begin{array}{l}\text { The capital-risk relationship is non-linear and } \\
\text { changes from positive to negative as franchise } \\
\text { value falls. For under-capitalized banks, capital } \\
\text { adequacy requirement cannot prevent risk-taking } \\
\text { behavior. In this situation the under-capitalized } \\
\text { banks just issue more subordinated debts to meet } \\
\text { the requirement of capital adequacy. }\end{array}$ \\
\hline $\begin{array}{l}\text { Altunbas et al. } \\
\text { (2007) }\end{array}$ & $\begin{array}{l}\text { Europe } \\
1992-2000\end{array}$ & $\begin{array}{l}\text { Seemingly } \\
\text { Unrelated } \\
\text { Regression }\end{array}$ & $\begin{array}{l}\text { Positive association is found between risk and } \\
\text { capital, indicating regulators' preference for capital } \\
\text { as a mean for the restriction of risk taking } \\
\text { activities. }\end{array}$ \\
\hline
\end{tabular}


Table 1 (cont.)

\begin{tabular}{|c|c|c|c|}
\hline Authors & $\begin{array}{l}\text { Country and } \\
\text { periods }\end{array}$ & $\begin{array}{l}\text { Methods } \\
\text { used }\end{array}$ & Results \\
\hline $\begin{array}{l}\text { Zong-yi et al. } \\
(2008)\end{array}$ & $\begin{array}{l}\text { China } \\
\text { 2004-2006 }\end{array}$ & GMM & $\begin{array}{l}\text { Changes in capital are negatively associated with } \\
\text { the changes in risk in a significant way, which } \\
\text { implies that increasing capital ratio is effective in } \\
\text { reducing portfolio risk. }\end{array}$ \\
\hline $\begin{array}{l}\text { Laeven and } \\
\text { Levine (2009) }\end{array}$ & $\begin{array}{l}1996-2001 \\
48 \text { countries }\end{array}$ & GMM & $\begin{array}{l}\text { Bank risk taking depends on the comparative } \\
\text { power of shareholders with the corporate } \\
\text { governance structure. The relation between bank } \\
\text { risk and capital regulations depends on each bank's } \\
\text { ownership structure. }\end{array}$ \\
\hline $\begin{array}{l}\text { Ho and Hsu } \\
\text { (2010) }\end{array}$ & $\begin{array}{l}\text { Taiwan } \\
\text { 1996-2006 }\end{array}$ & OLS & $\begin{array}{l}\text { The restrictions on capital adequacy ratios affect } \\
\text { the banks' risky investment strategies, as leverage } \\
\text { and market share are positively related. }\end{array}$ \\
\hline $\begin{array}{l}\text { Agoraki et al. } \\
(2011)\end{array}$ & $\begin{array}{l}\text { Europe } \\
1998-2005\end{array}$ & GMM & Capital requirements decrease risk. \\
\hline $\begin{array}{l}\text { Lee and Hsieh } \\
\text { (2013) }\end{array}$ & $\begin{array}{l}\text { Asian } \\
\text { countries } \\
\text { 1994-2008 } \\
\end{array}$ & GMM & $\begin{array}{l}\text { With the changes in the categories of banks, } \\
\text { commercial banks reveal the highest reverse } \\
\text { capital effect on risk. }\end{array}$ \\
\hline $\begin{array}{l}\text { Guidara et al. } \\
\text { (2013) }\end{array}$ & $\begin{array}{l}\text { Canada } \\
1982-2010\end{array}$ & 2SGMM & $\begin{array}{l}\text { There is no strong evidence that changes in capital } \\
\text { buffer impact changes in risks. There is no } \\
\text { significant relationship between capital buffers and } \\
\text { risk. The motive to hold an excess capital buffer } \\
\text { may be driven by market discipline. }\end{array}$ \\
\hline $\begin{array}{l}\text { Lee and Chih } \\
\text { (2013) }\end{array}$ & $\begin{array}{l}\text { China } \\
\text { 2004-2011 }\end{array}$ & OLS & $\begin{array}{l}\text { Strict regulation is good for bank stability i.e. } \\
\text { stricter regulations reduce risk, but strict regulation } \\
\text { is not good for efficiency. Capital adequacy ratio is } \\
\text { relevant for small banks and reduces risk. }\end{array}$ \\
\hline
\end{tabular}

They use a contingent-claims model and show that increased capital will not increase portfolio risk of banks. This is because; the value of the deposit insurance reduces as the capital increases.

Calem and Rob (1999) find U-shaped relationship between capital and risk-taking. According to them, as a bank's capital increases it first takes less risk then it will increase risk taking. On undercapitalized banks, a deposit insurance premium surcharge induces them to take more risk. Hussain and Hassan (2005) show that regulations cannot increase the capital adequacy ratio of banks in the developing countries but such regulations decrease the portfolio risk. To design and implement regulatory policies, attention should be given to the legal, environmental, business, cultural realities of developing countries.

For under-capitalized banks, Iwatsubo (2007) concludes that capital adequacy requirement cannot stop banks in risk-taking. This is because; banks just issue more subordinated debts to meet their requirement of capital. Laeven and Levine (2009) show that, by the comparative power of shareholders, bank risk taking varies 
Relationship between Risk-taking, Capital Regulation and Bank Performance: Empirical ...

positively. The relation between bank capital regulation and risk, restrictions on bank activities and deposit insurance policies depend on each bank's ownership structure.

\subsection{Relationship between capital regulation and performance}

Banks' level of performance is considered as an influential factor in the relationship between risk and capital regulation (Altunbas et al., 2007; Hughes \& Mester, 1998; Lee \& Hsieh, 2013). Table 2 shows a comprehensive literature survey on the relationship between capital regulation and performance.

There is a positive association between capital regulation and banking performance (Goddard, Molyneux, \& Wilson, 2004; Jacques \& Nigro, 1997; C.-C. Lee \& Hsieh, 2013; Lin et al., 2005; Mbizi, 2012; Samy Ben Naceur \& Kandil, 2009; Sami Ben Naceur \& Omran, 2011; Pasiouras \& Kosmidou, 2007; Rime, 2001).

Apart from positive relationship between capital regulation and performance, Zhang et al. (2008), Guidara et al. (2013) find no significant relationship between them. Zhang et al. (2008) suggest that commercial banks, under the constraint of capital, should allocate resources and augment their business to increase liquidity and profitability. Working on Canadian banks, Guidara et al. (2013) conclude that there is no strong evidence that changes in capital buffer (the difference between the banks' minimum capital requirements and capital levels) affect the performance measured by return on equity.

Mixed results are also found in the literature, for example, Goddard et al. (2004) find a positive relationship between capital regulation and performance for European banking in the period 1992-1998. On the other hand, Goddard, Liu, Molyneux, and Wilson (2010) conclude a negative relationship exists between capital regulation and performance in banking of European Union member countries between 1992 and 2007.

Some other studies focus on macroeconomic variables and other variables. For example, lannotta, Nocera, and Sironi (2007) show that profitability is lower for mutual banks and government-owned banks than that for privately owned banks. Pasiouras and Kosmidou (2007) illustrate that macroeconomic condition and financial market structure affect the banks' profitability along with the banks' specific characteristics. In addition to increase in profitability, higher capital adequacy ratio increases the cost of intermediation (Samy Ben Naceur \& Kandil, 2009). They mention that there are a number of factors that contribute positively to banks' profitability. Those factors are increase in management, reduction in implicit cost and higher capital requirements. In examining whether financial regulation affect the profit efficiency, Lee and Chih (2013) find that the capital adequacy ratio is relevant for small banks but irrelevant for large banks. 
Mohammad Morshedur RAHMAN, Ali Arshad CHOWDHURY \& Mouri DEY

Table 2. Literature on the Relationship between capital regulation and performance

\begin{tabular}{|c|c|c|c|}
\hline Authors & $\begin{array}{l}\text { Country and } \\
\text { periods }\end{array}$ & $\begin{array}{l}\text { Methods } \\
\text { used }\end{array}$ & Results \\
\hline $\begin{array}{l}\text { Jacques and } \\
\text { Nigro (1997) } \\
\end{array}$ & $\begin{array}{l}\text { US } \\
1990-1991 \\
\end{array}$ & $3 S L S$ & $\begin{array}{l}\text { Positive association is found between capital } \\
\text { and profitability. }\end{array}$ \\
\hline Rime (2001) & $\begin{array}{l}\text { Swiss Bank } \\
1989-1995\end{array}$ & $3 S L S$ & $\begin{array}{l}\text { Current earnings have a positive significant } \\
\text { impact on capital, which indicates that } \\
\text { profitable banks can increase their } \\
\text { capitalization from retained earnings. }\end{array}$ \\
\hline $\begin{array}{l}\text { Goddard et al. } \\
\text { (2004) }\end{array}$ & $\begin{array}{l}\text { Europe } \\
1992-1998\end{array}$ & $\begin{array}{l}\text { Dynamic } \\
\text { panel model }\end{array}$ & $\begin{array}{l}\text { There is positive association between } \\
\text { profitability and capital-to-assets ratio. }\end{array}$ \\
\hline Lin et al. (2005) & $\begin{array}{l}\text { Taiwan } \\
1993-2000\end{array}$ & OLS & $\begin{array}{l}\text { There are significant relationships between } \\
\text { various financial performances and capital } \\
\text { adequacy. }\end{array}$ \\
\hline $\begin{array}{l}\text { Pasiouras and } \\
\text { Kosmidou } \\
\text { (2007) } \\
\end{array}$ & $\begin{array}{l}\text { Europe } \\
1995-2001\end{array}$ & $\begin{array}{l}\text { Fixed Effects } \\
\text { Regression }\end{array}$ & $\begin{array}{l}\text { Capital is positively related to profitability. } \\
\text { Capital is the most significant determinant of } \\
\text { profitability. }\end{array}$ \\
\hline $\begin{array}{l}\text { Zong-yi et al. } \\
\text { (2008) }\end{array}$ & $\begin{array}{l}\text { China } \\
\text { 2004-2006 }\end{array}$ & GMM & $\begin{array}{l}\text { There is no notable relationship between } \\
\text { earnings and changes in capital. }\end{array}$ \\
\hline $\begin{array}{l}\text { Naceur and } \\
\text { Kandil (2009) }\end{array}$ & $\begin{array}{l}\text { Egypt } \\
1989-2004\end{array}$ & GMM & $\begin{array}{l}\text { In managing banks' portfolios, The interest of } \\
\text { shareholders increases for higher capital } \\
\text { adequacy. The result is a higher cost of } \\
\text { intermediation and profitability. }\end{array}$ \\
\hline $\begin{array}{l}\text { Naceur and } \\
\text { Omran (2011) }\end{array}$ & $\begin{array}{l}\text { Africa } \\
1989-2005\end{array}$ & GMM & $\begin{array}{l}\text { Bank capitalization has a positive significant } \\
\text { impact on profitability. }\end{array}$ \\
\hline Mbizi (2012) & Zimbabwe & $\begin{array}{l}\text { Description } \\
\text { Correlation } \\
\text { Method } \\
\end{array}$ & $\begin{array}{l}\text { There is a significant positive relationship } \\
\text { between commercial bank's capitalization } \\
\text { and its performance. }\end{array}$ \\
\hline $\begin{array}{l}\text { Lee and Hsieh } \\
\text { (2013) }\end{array}$ & $\begin{array}{l}\text { Asian } \\
\text { countries } \\
\text { 1994-2008 } \\
\end{array}$ & GMM & $\begin{array}{l}\text { With the changes in the categories of banks, } \\
\text { capital effect on profitability differently. }\end{array}$ \\
\hline $\begin{array}{l}\text { Guidara et al. } \\
(2013)\end{array}$ & $\begin{array}{l}\text { Canada } \\
1982-2010\end{array}$ & 2SGMM & $\begin{array}{l}\text { There is no strong evidence that changes in } \\
\text { banks' capital buffer impact changes in } \\
\text { performance i.e. there is no significant } \\
\text { relationship between capital buffers and } \\
\text { performance. }\end{array}$ \\
\hline
\end{tabular}

\subsection{Relationship between risk and performance}

Risk and performance relationship is an important area in the context of risk evaluation of banks. But strikingly it is observed that there are very few studies in literature that consider the relationship between risk and performance. $A$ comprehensive literature survey on the relationship between risk and performance 
Relationship between Risk-taking, Capital Regulation and Bank Performance: Empirical ...

is stated in Table 3. It is seen from the table that Kwan and Eisenbeis (1997) use simultaneous equations framework to test interrelationships among risk, capitalization and operating efficiency. They find there is a positive association between inefficiency and risk taking. Their result supports the moral hazard hypothesis, which implies that banks with poor performance are more vulnerable in risk-taking than banks with high performance.

Table 3. Literature on the Relationship between risk and performance

\begin{tabular}{|c|c|c|c|}
\hline Authors & $\begin{array}{l}\text { Country and } \\
\text { periods }\end{array}$ & Methods used & Results \\
\hline $\begin{array}{l}\text { Kwan and } \\
\text { Eisenbies (1997) }\end{array}$ & $\begin{array}{l}\text { US } \\
1987-1995\end{array}$ & $\begin{array}{l}\text { Simultaneous } \\
\text { equation method }\end{array}$ & $\begin{array}{l}\text { There is a positive impact of } \\
\text { inefficiency on risk-taking. The results } \\
\text { support the moral hazard hypothesis } \\
\text { that banks with poor performance } \\
\text { are more vulnerable to risk-taking. }\end{array}$ \\
\hline Lin et al. (2005) & $\begin{array}{l}\text { Taiwan } \\
1993-2000\end{array}$ & OLS & $\begin{array}{l}\text { The relationship between risk and } \\
\text { performance is negative and } \\
\text { statistically significant. }\end{array}$ \\
\hline $\begin{array}{l}\text { Naceur and } \\
\text { Omran (2011) }\end{array}$ & $\begin{array}{l}\text { Africa } \\
1989-2005\end{array}$ & GMM & $\begin{array}{l}\text { There is a significant positive impact } \\
\text { of credit risk on bank's profitability. }\end{array}$ \\
\hline $\begin{array}{l}\text { Guidora et al. } \\
\text { (2013) }\end{array}$ & $\begin{array}{l}\text { Canada } \\
1982-2010\end{array}$ & 2SGMM & $\begin{array}{l}\text { There is no strong evidence that } \\
\text { change in banks' capital buffer impact } \\
\text { banks' exposure to return on equity. }\end{array}$ \\
\hline $\begin{array}{l}\text { Zhang et al. } \\
\text { (2013) }\end{array}$ & $\begin{array}{l}\text { Brazil, Russic } \\
\text { India, China } \\
\text { 2003-2010 }\end{array}$ & $\begin{array}{l}\text { Stochastic Frontier } \\
\text { Analysis and Data } \\
\text { Envelopment } \\
\text { Analysis }\end{array}$ & $\begin{array}{l}\text { Banks having a low level of risks } \\
\text { perform better. }\end{array}$ \\
\hline
\end{tabular}

Lin et al. (2005) demonstrate that there is a significant negative relationship between insolvency risk and financial performances. In the examination market concentration, risk taking and bank performance from the emerging economies, Zhang, Jiang, Qu, and Wang (2013) show that there is a negative association between performance and market concentration. They also suggest that banks with lower level risk perform better than banks with high level of risk. Moreover, they conclude that banks in China and Brazil perform better for more favourable institutional infrastructure.

From the above comprehensive literature, it is seen that very few studies consider the interrelationship among risk-taking, capital regulation and performance. For example: Lin et al. (2005), Guidara et al. (2013) and C.-C. Lee and Hsieh (2013). In the study of Lin et al. (2005), they focus on risk-based capital adequacy, insolvency risk and financial performance. They use OLS technique for their analysis. Guidara et al. (2013) focus on Canadian banking and consider banks' capital buffer, risk and performance. By using GMM technique C.-C. Lee and Hsieh (2013) examine the impact of bank capital on profitability and risk in Asian banking. We augment the study of C.-C. Lee and Hsieh (2013). They used only two simultaneous equations to 
see the impact of capital on risk and profitability. In our study, we use three simultaneous equations to see the relationship between risk-taking, capital regulations and performance. Capital regulation (risk-based capital) is used instead of equity capital that is used in their study. Three alternative measures of risk are considered in this study. We consider capital market development and banking sector development as control variables, which are ignored in their study. Based on the above literature review, the study sets we design the following alternative hypotheses to test.

$\mathrm{H}_{1}$ : There is a significant negative relation between capital regulation and risk.

$\mathrm{H}_{2}$ : There is a significant positive relation between capital regulation and performance.

$\mathrm{H}_{3}$ : There is a significant negative relation between risk and performance.

$\mathrm{H}_{4}$ : Bank ownership has significant impact on capital regulation, risk and performance.

\section{Data and Variables}

Banking sector in Bangladesh in the present day context, as stated earlier, reveals that at the end of 2016, there are 56 commercial banks working in Bangladesh that consist of 39 private-owned banks, 6 state-owned banks, 9 foreign-owned banks, 2 state-owned development financial institutions. Government is the owner of stateowned banks. Private investors are the owner of private-owned banks. Foreign investors are the owners of foreign-owned banks. Finally, the state-owned development financial institutions are owned by government but used for special activities. The data is composed of selected 38 Bangladeshi commercial banks covering a period of 2007-2016. We exclude 11 commercial banks as they are new, 2 specialized banks as they do not run for commercial purposes. For unavailability of data, we also exclude 5 foreign-owned banks from our sample. As the information for all banks are not available for all years, we use an unbalanced panel data for not losing degrees of freedom. Thus samples composed of 38 banks in Bangladesh.

Data for capital regulation, risk measures and performance measure are obtained mainly from the annual reports of banks as well as from bank's individual website. The data for internal control variables are also obtained from annual reports and websites of banks. The data for micro economic variables are collected from the website of Bangladesh Bank (http://www.bangladesh-bank.org). The Table 4 (See in Econometric Model Section) presents the variables used for our study.

\section{Econometric Model}

We use three simultaneous equations to examine the relationships among risk, capital regulation and performance in Bangladeshi banking sector as used by Jacques and Nigro (1997), Altunbas et al. (2007), Rime (2001), Shrieves and Dahl (1992) and Kwan and Eisenbeis (1997). To account both cross correlation and 
endogeneity between the error terms we rely on GMM estimation to examine the relationships between risk-taking, capital regulation and performance. After examining a number of literature for examples, Altunbas et al. (2007), Samy Ben Naceur and Kandil (2009), C.-C. Lee and Hsieh (2013), Tan and Floros (2013), Fiordelisi, Marques-Ibanez, and Molyneux (2011), Francis and Osborne (2012), Jacques and Nigro (1997), Vollmer and Wiese (2013), Nier and Baumann (2006), Ayuso, Pérez, and Saurina (2004), Hussain and Hassan (2005), Ediz, Michael, and Perraudin (1998), we specify the empirical model by three simultaneous equations as given below:

$$
\begin{aligned}
& C A P_{i t}=\alpha_{0}+\alpha_{1} R I S K_{i t}+\alpha_{2} P E R F_{i t}+\alpha_{3} S I Z E_{i t}+\alpha_{4} L A B O U R_{i t}+\alpha_{5} R W A T A_{i t}+ \\
& \alpha_{6} \text { TLTA }_{i t}+\alpha_{7} I_{N F R_{t}}+\alpha_{8} G G D P_{t}+\alpha_{9} C M D_{t}+\alpha_{10} B S D_{t}+\alpha_{11} P C B_{i}+\varepsilon_{i t} \\
& \text { RISK }_{i t}=\beta_{0}+\beta_{1} \text { CAP }_{i t}+\beta_{2} P E R F_{i t}+\beta_{3} \text { SIZE }_{i t}+\beta_{4} \text { GOVS }_{i t}+\beta_{5} \text { LIQUIDITY }_{i t}+ \\
& \beta_{6} I N F R_{t}+\beta_{7} G G D P_{t}+\beta_{8} C M D_{t}+\beta_{9} B S D_{t}+\beta_{10} P C B_{i}+\varepsilon_{i t} \\
& \text { PERF } i t=\gamma_{0}+\gamma_{1} \text { CAP }_{i t}+\gamma_{2} \text { RISK }_{i t}+\gamma_{3} S I Z E_{i t}+\gamma_{4} \text { OFBSTA }_{i t}+\gamma_{5} \text { GOVS }_{i t}+ \\
& \gamma_{6} C I_{i t}+\gamma_{7} F U N D C_{i t}+\gamma_{8} I D_{i t}+\gamma_{9} I N F R_{t}+\gamma_{10} G G D P_{t}+\gamma_{11} C M D_{t}+\gamma_{12} B S D_{t}+ \\
& \gamma_{13} P C B_{i}+\varepsilon_{i t}
\end{aligned}
$$

Where the i subscript denotes the cross-sectional dimension across banks, and $t$ denotes the time dimension.

CAP is the proxy for capital regulation for banks and we use Capital Adequacy Ratio (CAR) as the measure for capital regulation. According to the capital regulation in Bangladesh, banks have to maintain minimum capital requirement which is $10 \%$ of RWA. We use RISK as the variable for bank's risk. Our main risk measure is NPLTL. We use three alternative measures for risk. They are: (i) Volatility in ROA (SROA), (ii) Volatility in ROE (SROE) and (iii) Loan loss provision to total loan (LLPTL). Return on Assets (ROA) is used as a proxy for bank performance (PERF).

We use SIZE, LIQUIDITY, OFBSTA, LABOUR, RWATA, GOVS, FUNDC, TLTA, CTI, ID, as internal control variables for individual bank and some macroeconomic factors (BSD, CMD, INFR, GGDP,OWND) affecting the relationships among risk, capital regulation and performance. $\varepsilon_{i t}$ is the random error term.

Equation (1) examines whether level of capital is affected by the changes in risk and performance, where as equation (2) examines whether level of capital and performance reflect the changes in bank risk. Finally equation (3) shows the effect of capital and risk on performance. CAP is the ratio of regulatory capital to risk weighted assets. We use the ratio of Non-performing loan to total loans as the main measure for bank's risk. A high level of ratio denotes high level of risk. The volatility of ROE and ROA is measured as the standard deviation of ROE and ROA respectively. The third alternative measure of risk is the ratio of loan loss provision to total loan (LLPTL). High value of LLPTL shows high level of risk, and the high value of standard deviation of ROE and ROA also shows high level of risk. We use ten bank specific internal control variables and five macroeconomic variables, because 
these variables are important in examining the relationships among risk, capital regulation and performance.

\section{Table 4. Description of the Variables}

\begin{tabular}{|c|c|c|}
\hline Variables & Symbol & Definition \\
\hline Capital Regulation & CAP & $\begin{array}{l}\text { Regulatory capital to risk weighted assets, i.e. Capital } \\
\text { Adequacy Ratio (CAR) }\end{array}$ \\
\hline \multirow[t]{4}{*}{ Risk } & NPLTL & Ratio of nonperforming loans to total loans \\
\hline & SROA & Standard deviation of return on assets (Volatility in ROA) \\
\hline & SROE & Standard deviation of return on equity (Volatility in ROE) \\
\hline & LLPTL & Ratio of loan loss provisions to total loans \\
\hline Performance & PERF & Return on Assets (ROA) \\
\hline \multicolumn{3}{|l|}{$\begin{array}{l}\text { Bank internal control } \\
\text { variables }\end{array}$} \\
\hline Bank size & SIZE & Natural logarithm of total assets \\
\hline Liquidity & LIQUIDITY & Ratio of total loans to total deposits \\
\hline $\begin{array}{l}\text { Risk weighted assets to } \\
\text { total assets }\end{array}$ & RWATA & Ratio of risk weighted assets to total assets \\
\hline Nontraditional activity & OFBSTA & Ratio of off balance sheet items to total assets \\
\hline Labor efficiency & LABOUR & Ratio of gross total revenue to number of employees \\
\hline Government Securities & GOVS & $\begin{array}{l}\text { Ratio of investment in government securities to total } \\
\text { assets }\end{array}$ \\
\hline Cost to income & CTI & Ratio of total cost to total income \\
\hline Income diversification & ID & Ratio of non-interest income to total income \\
\hline Total loanto total assets & TLTA & Ratio of total loans to total assets \\
\hline Funding Cost & FUNDC & Ratio of interest expense to total deposits \\
\hline \multicolumn{3}{|l|}{$\begin{array}{l}\text { Macroeconomic } \\
\text { Variables }\end{array}$} \\
\hline $\begin{array}{ll}\text { Banking } & \text { sector } \\
\text { development } & \end{array}$ & BSD & $\begin{array}{l}\text { The ratio of banking industry assets to total gross } \\
\text { domestic products }\end{array}$ \\
\hline $\begin{array}{l}\text { Capital market } \\
\text { development }\end{array}$ & CMD & $\begin{array}{l}\text { The ratio of market capitalization of ordinary shares of } \\
\text { banks to total gross domestic products }\end{array}$ \\
\hline Inflation rate & INFR & Annual inflation rate \\
\hline Growth in GDP & GGDP & Annual growth in real gross domestic product \\
\hline Private bank dummy & PCB & $\begin{array}{l}\text { Equals } 1 \text { if the banks is a private commercial bank and } \\
\text { zero for otherwise }\end{array}$ \\
\hline
\end{tabular}

\section{Empirical Results}

Empirical discussion is presented in three parts. Part 1 discusses about the descriptive statistics of all variables both dependent and independent. Part 2 discusses the correlation among the variables and part 3 explores regressionanalysis.

\subsection{Descriptive Statistics}

The Table 5 shows the descriptive statistics of all variables. There are three divisions in descriptive statistics. 
Relationship between Risk-taking, Capital Regulation and Bank Performance: Empirical ...

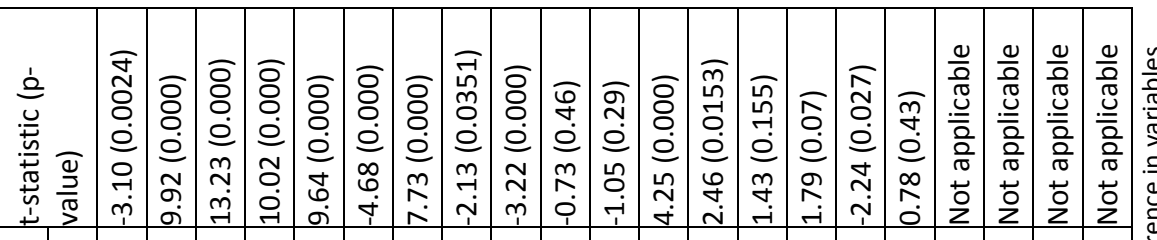

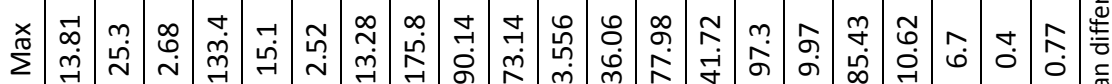

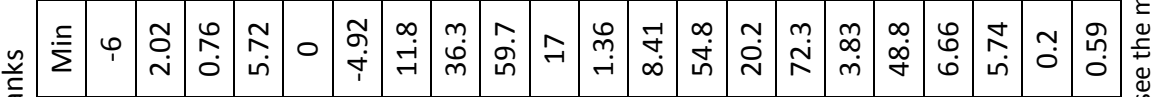

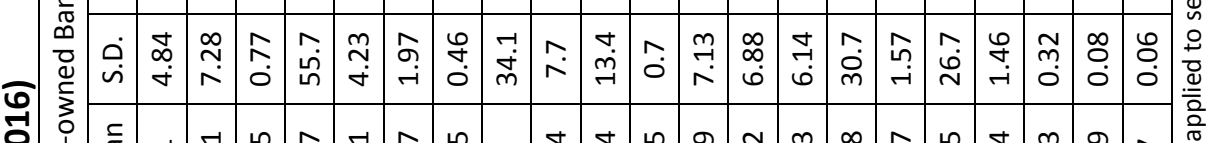

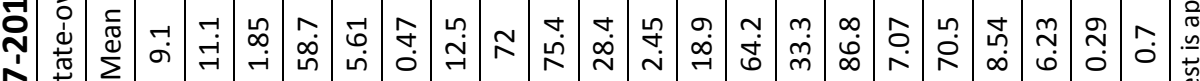

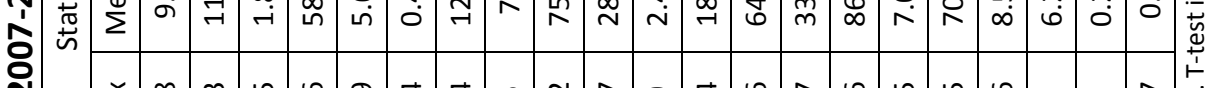

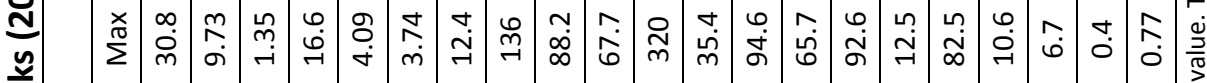

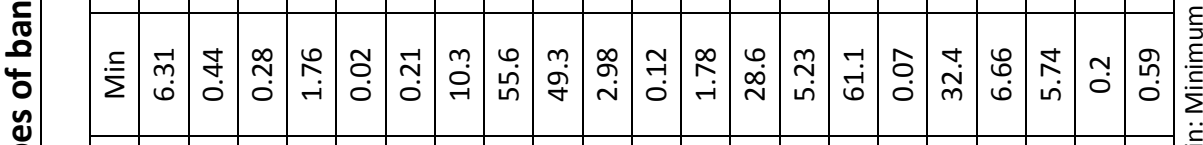

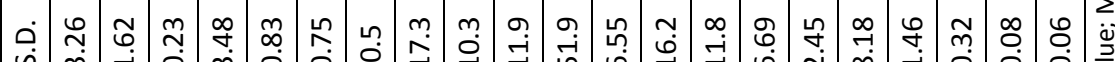

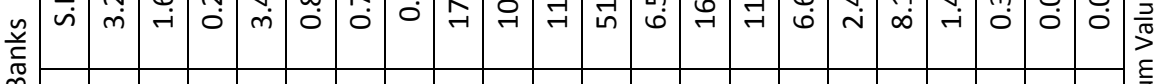

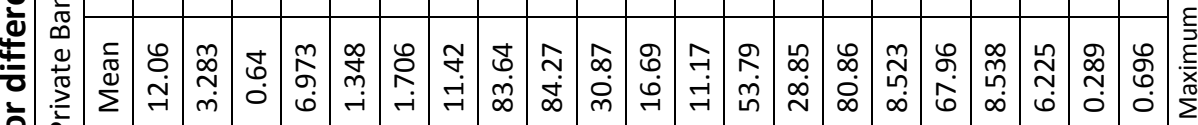

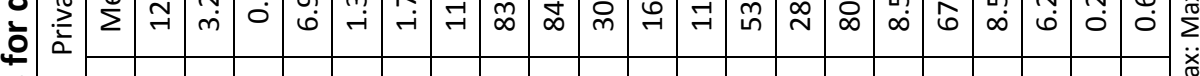

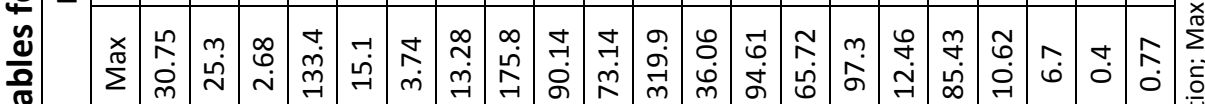

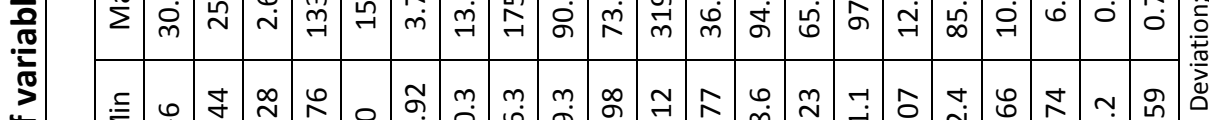

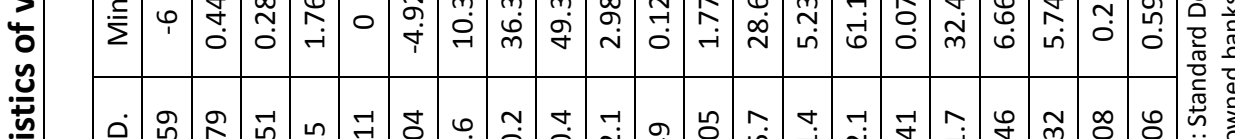

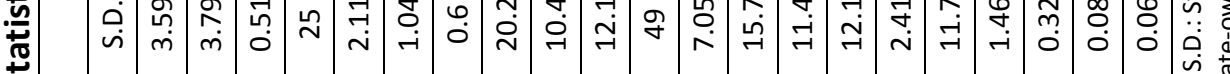

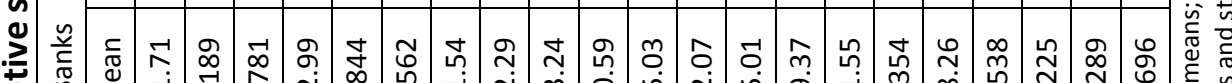

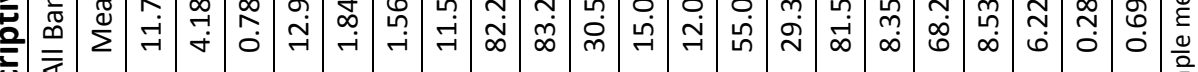

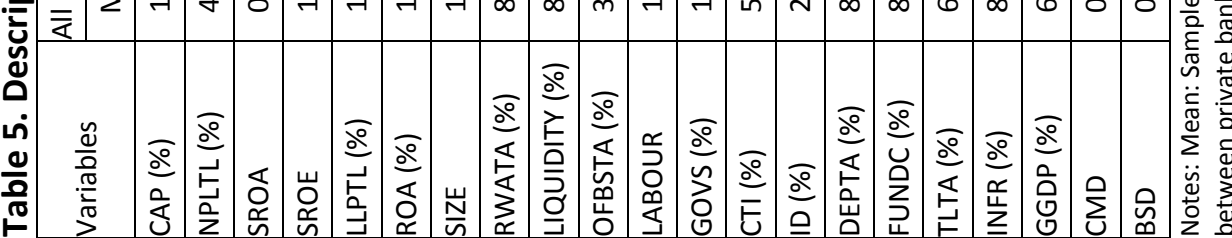


First four columns show the statistics for all banks, second four columns show the statistics for private commercial banks and third four columns show the statistics for state-owned commercial banks. From the table we see that the average CAP (Capital Adequacy Ratio) ratio is $11.1713 \%$, when all banks are considered, which is higher than the regulatory requirements of $10 \%$. But the average capital adequacy ratio for private commercial banks $(12.057 \%)$ is higher than the average ratio for state-owned banks (9.101\%). Highest value of CAP is $30.750 \%$ for the private banks and $13.810 \%$ for state-owned banks. On the other hand, the lowest value of CAP is $6.310 \%$ for private banks and $-6.000 \%$ for state-owned banks.

Average risk measured by NPLTL and LLPTL are $3.283 \%$ and $1.348 \%$ for private banks. For the state-owned banks the ratios are $11.072 \%$ and $5.609 \%$ respectively. Average risk measured by SROA and SROE for private banks are $0.277 \%$ and $1.762 \%$ respectively. On the contrary, the ratios for the state-owned banks are $1.850 \%$ and $58.683 \%$ respectively. For the all four measures of risk, the state-owned banks have the higher risk than the private commercial banks. From the table it is seen that average performance measured by ROA is $1.706 \%$ for private banks. The ratio is $0.465 \%$ for state-owned banks. The performance of private commercial banks is better than the performance of state-owned commercial banks. From the table we see that the private banks are more liquid and efficient in terms of revenue per labour than that of state-owned banks. State-owned banks have more investment in government securities. The average liquidity for all banks is $83.241 \%$, i.e. $83.241 \%$ of deposits are used for loan and advances to the customers. State-owned banks are more diversified in income sources. The average cost to income ratio is $55.007 \%$ for all banks. The average inflation and real growth in GDP are $8.538 \%$ and $6.225 \%$ respectively for a period $2007-2016$. Finally, the $p$-value for t-test for most of the variables is significant (see Table-5 in Appendices), hence null hypothesis of no significance difference between means of variables for private and state-owned banks is rejected. Therefore, there is a significant difference between means of variables for private and state-owned banks.

\subsection{Correlation Analysis}

Table 6 shows the correlation among all the variables. Our primary concern is to see the interrelationship among the risk, capital regulation and performance of banks. We use some banks' internal control variables as well as some macroeconomic variables to explain the relationship among risk, capital regulation and performance. From the Table 8 we see that regulatory capital is negatively related with four measures of risk (NPLTL, SROA, SROE, and LLPTL) and the relations are significant at $1 \%$ level for all risk measures. The relationship between regulatory capital and performance (ROA) is positive and significant at $1 \%$ level. It means that banks with more regulatory capital perform better. Capital regulation has significant negative relations with SIZE, GOVS, DEPTA, FUNDC and TLTA. 
Relationship between Risk-taking, Capital Regulation and Bank Performance: Empirical ...

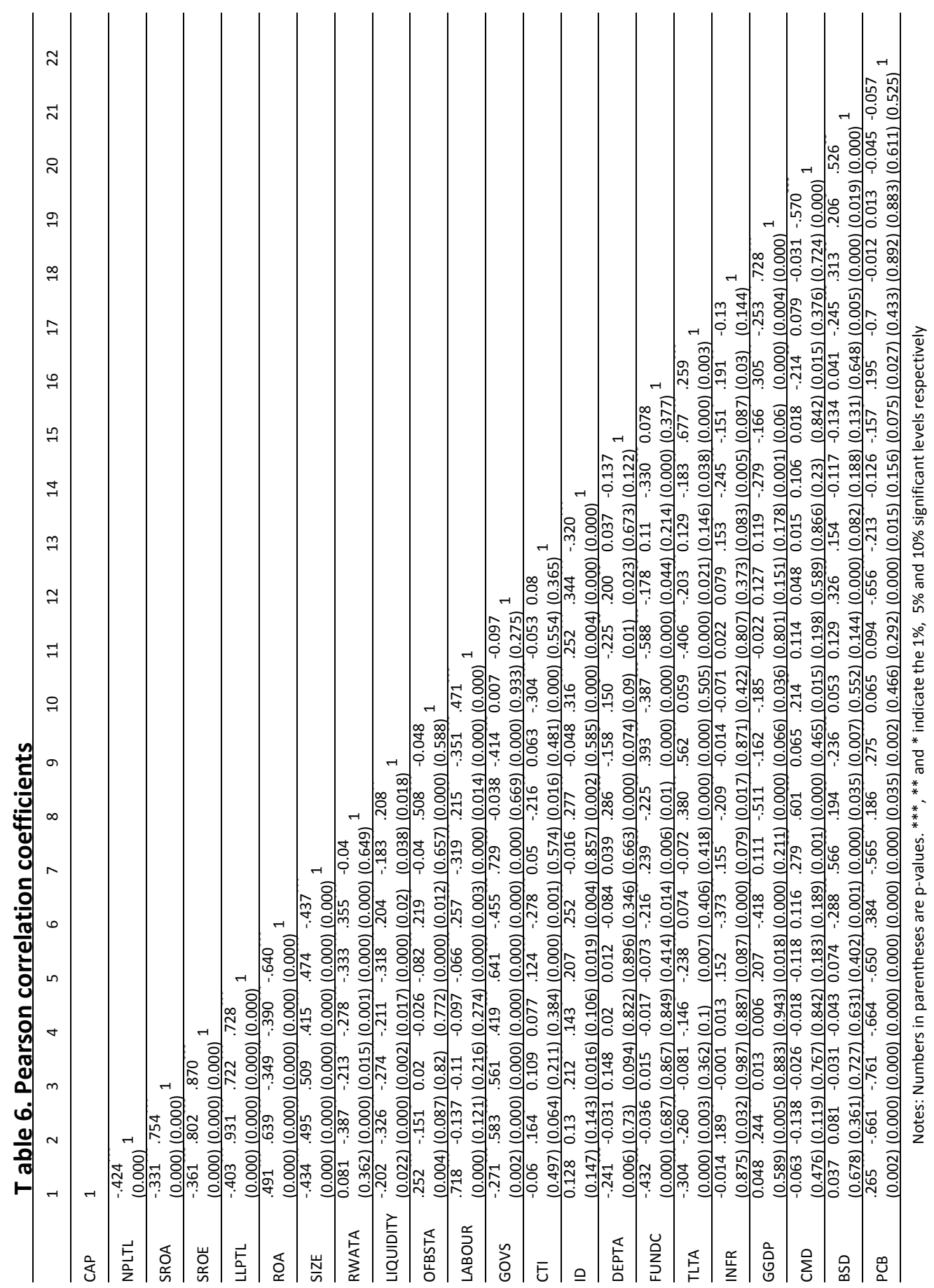


On the other hand, regulatory capital has significant positive relation with OFBSTA and LABOUR. Capital regulation also has a positive relation with PCB dummy. It means that private commercial banks hold more regulatory capital.

We observe from the Table 6 that there is a negative relationship between all risk measures and performance and the relations are significant at $1 \%$ level for all risk measures. It means that with lower risk banks perform better. SIZE is positively (significant at $1 \%$ level) related with risk and negatively (significant at $1 \%$ level) related with performance i.e. large banks take more risk and perform badly. LIQUIDITY has a positive significant relation with all risk measures and has a positive relation with performance. GOVS is positively related with risk and negatively related with performance. From the PCB dummy, we can conclude that private commercial banks take lower risk and perform better than that of stateowned banks. There are some correlations which are small (less than 0.4 ) and some correlations are ambiguous, indicating that we need to run a regression analysis so that we can clearly identify the relationships among the variables.

\subsection{Regression Analysis}

This section deals with the results from the simultaneous model described above where risk, capital regulation and profitability are endogeneous variables. In this study we apply GMM system panel estimator developed by Arellano and Bover (1995) and Blundell and Bond (2000) with cross-section random effect estimation as Hausman test supports that the three variables are endogeneous and Hausman test for Random or Fixed effect model supports the use of random effect over fixed effects models. The random effect specification for panel observations is supported by the Breusch-Godfrey ((Breusch, 1978; Godfrey, 1978) Lagrange Multiplier test (LM test), which reject the null hypothesis that errors are independent within banks. A White test ((White, 1980) is also applied to examine cross sectional heteroscedasticity, and the null hypothesis of hosmoskedasticity is rejected. Sargan test for over identification is also applied, and the null hypothesis of over identification restrictions are valid cannot be rejected. Hence, ordinary least square has not been used in the study. Differing from other system estimation methods of the simultaneous equations, the GMM allows for the serial correlation of random errors and heterogeneity(Zhang, Jun, \& Liu, 2008).

Table 7, 8, and 9 show the estimated results from GMM estimator. Our main risk variable is NPLTL. We use three other alternatives of risk measures; they are SROA, SROE, and LLPTL. Our main concern is to see the interrelationship among risk, capital regulation and bank performance. We investigate the impacts of bank internal control variables and macroeconomic variables on the relationship among risk, capital regulation and performance. In the regression analysis we have three parts: part 1 discusses on the impact of risk and performance on capital, in part 2 we discuss the impact of capital and performance on risk and in part 3 we show the impact of capital and risk on performance. 
Relationship between Risk-taking, Capital Regulation and Bank Performance: Empirical ...

\subsubsection{Impact of risk and performance on capital regulation}

Table 7 shows the empirical results of regression for equation 1 in econometric modelling.

Table 7. Impact of risk and performance on capital regulation

\begin{tabular}{|c|c|c|c|c|}
\hline Variables & Model 1 & Model 2 & Model 3 & Model 4 \\
\hline & RISK=NPLTL & RISK=SROA & RISK=SROE & RISK=LLPTL \\
\hline $\mathrm{C}$ & $-6.234(-0.66)$ & $-2.922(-0.36)$ & $4.231(0.54)$ & $-7.1176(-0.66)$ \\
\hline NPLTL & $-0.3065 *(-1.72)$ & & & \\
\hline SROA & & $-2.6163 * *(-2.54)$ & & \\
\hline SROE & & & $-0.0617 * *(-2.46)$ & \\
\hline LLPTL & & & & $-30.114 *(-1.65)$ \\
\hline ROA & $\begin{array}{l}0.5543^{*} \\
(1.90)\end{array}$ & $\begin{array}{l}0.915^{*} \\
(1.68)\end{array}$ & $\begin{array}{l}0.7152^{*} \\
(1.69)\end{array}$ & $0.9523 * *(2.66)$ \\
\hline SIZE & $\begin{array}{l}-0.7031^{*} \\
(-1.72)\end{array}$ & $\begin{array}{l}-0.51625 \\
(-0.87)\end{array}$ & $\begin{array}{l}-0.9184^{*} \\
(-1.88)\end{array}$ & $\begin{array}{l}-0.7348 \\
(-1.55)\end{array}$ \\
\hline LABOUR & $0.0375 * * *(4.66)$ & $0.0521 * * *(4.36)$ & $0.0342 * * *(4.24)$ & $0.0531^{* * *}(4.88)$ \\
\hline RWATA & $-0.9556(-1.20)$ & $-1.2167(-0.97)$ & $-2.4872(-1.52)$ & $-1.0619(-1.26)$ \\
\hline TLTA & $-1.0105(-0.73)$ & $-1.0176(-0.64)$ & $-1.2378(-0.89)$ & $-0.7543(-0.68)$ \\
\hline INFR & $-0.324 *(-1.69)$ & $-0.4231 *(-1.77)$ & $-0.1755 *(-1.77)$ & $-0.8072 *(-1.75)$ \\
\hline GGDP & $2.0882 * *(2.62)$ & $2.1059 * *(2.13)$ & $2.1085 *(1.69)$ & $2.1458 * *(2.54)$ \\
\hline CMD & $6.1063(1.52)$ & $6.7155 * *(1.99)$ & $5.7631 *(1.72)$ & $6.5263 *(1.67)$ \\
\hline BSD & $13.3872 *(1.85)$ & $11.2382 *(1.58)$ & $10.1537 *(1.78)$ & $11.8756 * *(2.19)$ \\
\hline PCB & $1.7712 * *(2.11)$ & $2.1236 * *(1.99)$ & $2.9234 * *(2.35)$ & $1.8577 *(1.75)$ \\
\hline$\overline{\text { Adjusted } \mathrm{R}^{2}}$ & 72.54 & 70.11 & 77.06 & 72.18 \\
\hline $\begin{array}{l}\text { Hausman Test } \\
\text { for Endogeneity, } \\
F(p \text {-value) }\end{array}$ & $20.0379(.000)$ & $20.6315(.000)$ & $20.9035(.000)$ & $21.2654(.000)$ \\
\hline $\begin{array}{l}\text { White test for } \\
\text { Heteroskedastic } \\
\text { ity, p-value }\end{array}$ & 0.000 & 0.000 & 0.000 & 0.000 \\
\hline $\begin{array}{l}\text { Breusch- } \\
\text { Godfrey Serial } \\
\text { correlation LM } \\
\text { test, p-value }\end{array}$ & 0.939 & 0.941 & 0.889 & 0.509 \\
\hline $\begin{array}{l}\text { Hausman Test } \\
\text { for Fixed or } \\
\text { Random Effect, } \\
\text { p-value }\end{array}$ & 1.000 & 1.000 & 1.000 & 1.000 \\
\hline $\begin{array}{l}\text { Sargan test ( } p- \\
\text { value) }\end{array}$ & 0.385 & 0.323 & 0.193 & 0.423 \\
\hline Observations & 320 & 320 & 320 & 320 \\
\hline $\begin{array}{l}\text { Number of } \\
\text { banks }\end{array}$ & 38 & 38 & 38 & 38 \\
\hline
\end{tabular}

Notes: The table shows the empirical results from GMM panel estimator. Dependent variable is capital for all four models. ${ }^{* * *},{ }^{* *}$ and ${ }^{*}$ indicate significance at the $1 \%, 5 \%$ and $10 \%$ respectively. For Hausman test $\mathrm{p}$-values are in parentheses. $\mathrm{t}$-statistics are shown in parentheses. 
We find significantly negative relationship between capital adequacy and risk measures (proxied by NPLTL, SROA, SROE and LLPTL) which supports the results of Jacques and Nigro (1997), Zhang, Wu, et al. (2008), Agoraki et al. (2011), Lee and Hsieh (2013), T.-H. Lee and Chih (2013) but opposite to the results of Shrieves and Dahl (1992), Blum (1999), Rime (2001), Lin et al. (2005), Altunbas et al. (2007). As tvalues are significant for all four models we reject the null hypothesis and accept the alternative hypothesis. The negative relationship indicates that if the banks reduce risk by $1 \%$ then they increase capital adequacy ratio by $0.31 \%$ for NPLTL, $2.62 \%$ for SROA, $0.06 \%$ for SROE and $30.11 \%$ for LLPTL. There is a positive significant impact from performance to capital i.e. if the banks increase their performance the capital adequacy ratio also increases. The t-values are significant for all models, so we reject the null hypothesis and accept the alternative hypothesis of positive significant association between capital and performance.

This result supports the findings of Jacques and Nigro (1997), Rime (2001), (Goddard et al., 2004), (Lin et al., 2005), (Pasiouras \& Kosmidou, 2007), (Samy Naceur \& Kandil, 2009), (Sami Ben Naceur \& Omran, 2011), (Mbizi, 2012), (C.-C. Lee \& Hsieh, 2013). A $1 \%$ increase in performance would increase the capital adequacy ratio by $0.55 \%$ to $0.95 \%$. The $p$-value of Hausman test for Model $1,2,3$ and 4 is 0.000 (significant at $1 \%$ level), which implies that the risk, capital and performance are simultaneously determined. The $p$-value for Sargan test for Model 1, 2, 3, and 4 is not significant, so we cannot reject the null hypothesis that over identification restrictions are valid. Serial correlation test does not reject the null hypothesis of no serial correlation. Among the control variables, The SIZE has a significant negative impact on capital which means that the larger bank has the lower amount of capital adequacy ratio. LABOUR has a significant positive relation with capital adequacy ratio. As the management of banks takes part in decision making of capital adequacy ratio, the labour efficient bank holds more capital than those banks having lower labour efficiency. Inflation has a negative significant effect on capital, as the inflation increases by $1 \%$ the capital adequacy ratio decreases by $0.32 \%$ to $0.81 \%$. There is positive significant relation between growth in real GDP and capital.

Positive significant relationships are also found between capital and capital market development as well as banking sector development. There is a significant positive relationship between capital adequacy ratio and bank ownership dummy. For this relationship t-values are significant for all four models, so we reject the null hypothesis of no significant association between capital adequacy and bank ownership. We accept the alternative hypothesis of significant and positive association between capital and ownership dummy. We can say that private commercial banks hold more capital adequacy than those of state-owned banks. From the adjusted R-squared we can conclude that the $72.74 \%, 70.11 \%, 77.06 \%$ and $72.18 \%$ variation in capital is explained by the Model 1, 2, 3 and 4 respectively. 
Relationship between Risk-taking, Capital Regulation and Bank Performance: Empirical ...

\subsubsection{Impact of capital regulation and performance on risk}

Table 8 reports the empirical results when equation 2 from econometric modelling is used.

Table 8. Impact of capital regulation and performance on risk

\begin{tabular}{|c|c|c|c|c|}
\hline \multirow{2}{*}{ Variables } & Model 5 & Model 6 & Model 7 & Model 8 \\
\hline & RISK=NPLTL & RISK=SROA & RISK=SROE & RISK=LLPTL \\
\hline C & $30.2316 *(1.92)$ & $8.9248(1.52)$ & $20.2454(0.89)$ & $\begin{array}{c}0.5228 * * * \\
(2.91))\end{array}$ \\
\hline CAP & $-0.3473 * * *(-2.77)$ & $-0.0708 * * *(-2.79)$ & $-0.0788(-0.44)$ & $-0.0143 * *(-2.34)$ \\
\hline ROA & $-0.4462 * * *(-2.65)$ & $-0.4321 * *(-2.49)$ & $-1.089(-0.73)$ & $0.0152 * *(2.33)$ \\
\hline NPLTL(-1) & $0.7715^{* * *}(15.45)$ & & & \\
\hline SROA $(-1)$ & & $0.672 * * *(9.11)$ & & \\
\hline SROE(-1) & & & $0.6883 * * *(8.46)$ & \\
\hline LLPTL(-1) & & & & $0.2953 * * *(3.11)$ \\
\hline SIZE & $-1.8711 * * *(-2.99)$ & $-0.2075^{*}(-1.73)$ & $-0.5986(-0.78)$ & $-0.0234 * *(-2.49)$ \\
\hline GOVS & $0.7461 * *(2.18)$ & $-0.0177(-1.43)$ & $0.0608(0.88)$ & $0.0017^{* *}(2.21)$ \\
\hline LIQUIDITY & $-1.3743(-1.23)$ & $-0.4825(-1.52)$ & $2.5301((0.38)$ & $-0.0042(-0.44)$ \\
\hline INFR & $0.4743(1.52)$ & $0.0792(0.827)$ & $-0.6253(-0.74)$ & $0.0078^{* * *}(3.12)$ \\
\hline GGDP & $-0.6823(-0.33)$ & $0.1764(0.67)$ & $3.7923(0.98)$ & $-0.0331(-1.52)$ \\
\hline CMD & $-0.1004(-1.29)$ & $-0.00207(-0.89)$ & $0.0016(0.50)$ & $-0.0028 * *(-2.39)$ \\
\hline BSD & $3.9314 *(1.73)$ & $0.7356(1.45)$ & $-3.4291(-0.79)$ & $0.0462 * * *(2.78)$ \\
\hline PCB & $-11.0279 * * *(-5.26)$ & $-1.892 * * *(-7.34)$ & $-3.6395 * * *(-4.73)$ & $-0.072^{* * *}(-5.33)$ \\
\hline${\text { Adjusted } \mathrm{R}^{2}}^{2}$ & 53.78 & 47.93 & 49.38 & 50.35 \\
\hline $\begin{array}{l}\text { Hausman Test for } \\
\text { Endogeneity, F } \\
\text { (p-value) } \\
\end{array}$ & $53.1261(0.000)$ & $43.7285(0.000)$ & $27.4572(0.000)$ & $17.8437(0.000)$ \\
\hline $\begin{array}{l}\text { White test for } \\
\text { Heteroskedasticity } \\
\text {, p-value }\end{array}$ & 0.000 & 0.000 & 0.000 & 0.000 \\
\hline $\begin{array}{l}\text { Breusch-Godfrey } \\
\text { Serial correlation } \\
\text { LM test, p-value }\end{array}$ & 0.017 & 0.013 & 0.011 & 0.016 \\
\hline $\begin{array}{l}\text { Hausman Test for } \\
\text { Fixed or Random } \\
\text { Effect, } p \text {-value }\end{array}$ & 1.000 & 1.000 & 1.000 & 1.000 \\
\hline $\begin{array}{l}\text { Sargan test ( } p- \\
\text { value) }\end{array}$ & 0.872 & 0.475 & 0.739 & 0.273 \\
\hline Observations & 320 & 320 & 320 & 320 \\
\hline Number of banks & 38 & 38 & 38 & 38 \\
\hline
\end{tabular}

Notes: The table shows the empirical results from GMM panel estimator. Dependent variable is risk for all four models measured by NPLTL, SROA, SROE and LLPTL for Model 5, 6, 7 and 8 respectively. ${ }^{* * *},{ }^{* *}$ and $*$ indicate significance at the $1 \%, 5 \%$ and $10 \%$ respectively. For Hausman test $p$-values are in parentheses. t-statistics are shown in parentheses.

From the table we see that capital has negative significant impact on all risk measures (Model 5, 6, 7, and 8) which supports the results of Jacques and Nigro 
(1997), Zhang, Wu, et al. (2008), Agoraki et al. (2011), Lee and Hsieh (2013), Lee and Chih (2013) but opposite to the results of Shrieves and Dahl (1992), Blum (1999), Rime (2001), Lin et al. (2005), Altunbas et al. (2007). The result suggests that a $1 \%$ increase in capital adequacy ratio would decrease risk by $0.0143 \%$ to $0.3473 \%$. There is a significant negative relation between risk (proxied by NPLTL, SROA, and SROE) and performance which supports the findings of Kwan and Eisenbeis (1997), Lin et al. (2005), J. Zhang et al. (2013) but does not support the findings of (Sami Ben, Naceur \& Omran, 2011); but the relation is positive when risk is measured by LLPTL.

SIZE has a negative significant impact on risk which varies from 0.02 to 1.8711 . This implies that larger banks take lower risk. Investment in government security has a positive impact on risk. Usually banks invest in government security to reduce their risk. It is also seen from the table that more liquid banks take lower risk as the relationship between LQUIDITY and RISK is negative.

Among the macroeconomic variables, banking sector development has a significant positive impact on risk (Model 5 and 6). This implies that banks take more risk as the banking sector is developed. Bank ownership dummy has a significant negative impact on risk. This suggests that private commercial banks take lower risk than state-owned banks. For this relationship t-values are significant for all four models, so we reject the null hypothesis of no significant association between risk and bank ownership. We accept the alternative hypothesis of significant and negative association between risk and ownership dummy.

In Table 8, the Hausman test implies that the capital and performance are endogeneous variables in risk equation. The $p$-value of Sargan test is insignificant for Model 5, 6, 7, and 8 which means that we have valid instruments. From the $p$ value of serial correlation test we cannot reject the null hypothesis of no serial correlation. The adjusted R-squared shows that $53.78 \%, 47.93 \%, 49.38 \%$ and $50.35 \%$ variation in risk is explained by the Model $5,6,7$, and 8 respectively.

\subsubsection{Impact of capital regulation and risk on performance}

Table 9 depicts the empirical result when equation 3 from econometric modelling is used. From the table we see that capital has a positive significant affect on banks' performance. This result supports the findings of Jacques and Nigro (1997), Rime (2001), Goddard et al. (2004), Lin et al. (2005), Pasiouras and Kosmidou (2007), Samy Naceur and Kandil (2009), Sami Ben Naceur and Omran (2011), Mbizi (2012), C.-C. Lee and Hsieh (2013). The coefficients of CAP are around 0.09-0.11, implying a $1 \%$ increase in capital increases the performance by $0.09 \%-0.11 \%$. Risk has a significant negative impact on performance for all risk measures (Model 9, 10, 11, and 12). The coefficients of risk are around $0.02-22.16$ which means that $1 \%$ reduction in risk will increase the performance by $0.02 \%-22.16 \%$. The $t$-values for the coefficients of risk for Model 9, 10, 11 and 12 are significant, so we reject the null hypothesis and accept the alternative hypothesis of negative significant 
Relationship between Risk-taking, Capital Regulation and Bank Performance: Empirical ...

association between risk and performance. Among the control variables, SIZE and ID have significant positive impact on performance which implies that large banks perform better than small one. The banks having more income diversification perform better. GOVS has a negative significant impact on performance, as the investment in government securities increases the performance decreases. Among the macroeconomic variables, CMD has significant positive impact on performance. On the other hand, BSD has a significant negative impact on performance. It implies that as banking sector developed the banks' performance reduces. This is because the banks have to compete with each other. Bank ownership does not affect the performance of banks significantly. As t-values for this relationship is not significant, we cannot reject the null hypothesis of no significant association between ownership and performance.

In Table 9, the Hausman test implies that the capital and risk are endogeneous variables in performance equation. The $p$-value of Sargan test is insignificant for Model 9, 10, 11, and 12 which means that we have valid instruments. From the $p$ value of serial correlation test we cannot reject the null hypothesis of no serial correlation. From the adjusted R-squared we can conclude that $64.41 \%, 54.05 \%$, $57.14 \%$ and $68.55 \%$ variations in performance is explained by the Model $9,10,11$, and 12 respectively.

\section{Robustness Analysis}

Robustness analysis can be done by using many options; for example (i) different alternative measures of the variables can be used and then run the regression accordingly or (ii) different regression techniques for example 2SLS instead of GMM can be used to run the regression to see whether similar results are obtained. In this study different alternative measures of variables have been used to see the robustness of the model.

The following changes are made in the empirical models to check the robustness of the results. First, we replace the credit risk by LLPNPL and overall risk by ZSCORE. ZSCORE is a measure of default risk and is calculated by ROA plus the CAR divided by the standard deviation of ROA. For normalization, we have used natural logarithm of ZSCORE. Second, we use another measure of capital i.e. shareholders' equity to TA (EQUITY) is used instead of CAR. Third, ROE is used as a measure of PROF in place of ROA. Table A1 (see in Appendices) report the estimation results after using above modification. In model 13 and 14 capital is dependent variable, in model 15 and 16 risk is the dependent variable and in model 17 and 18 performance is the dependent variable.

Comparing with the benchmark results in Table 7 to 9, the association between either CR and risk or between CR and profitability or between risk and profitability shows the exact equal direction i.e. there is a significant negative association between $\mathrm{CR}$ and risk, a negative relationship between risk and profitability and a positive and significant relationship between CR and profitability. 
Mohammad Morshedur RAHMAN, Ali Arshad CHOWDHURY \& Mouri DEY

Table 9. Impact of capital regulation and risk on performance

\begin{tabular}{|c|c|c|c|c|}
\hline Variables & Model 9 & Model 10 & Model 11 & Model 12 \\
\hline & RISK=NPLTL & RISK=SROA & RISK=SROE & RISK=LLPTL \\
\hline $\mathrm{C}$ & $-4.01535(-0.82)$ & $-3.40729(-0.77)$ & $-3.8951(-0.83)$ & $-4.6349(-1.09)$ \\
\hline CAP & $0.06573 * *(2.47)$ & $\begin{array}{c}0.119266^{* *} \\
(2.35)\end{array}$ & $0.2285^{* * *}(2.99)$ & $0.1139 * * *(2.98)$ \\
\hline NPLTL & $\begin{array}{c}-0.12933^{* * *} \\
(-2.83) \\
\end{array}$ & & & \\
\hline SROA & & $\begin{array}{c}-1.09158^{* *} \\
(-2.52)\end{array}$ & & \\
\hline SROE & & & $-0.0158^{* *}(-2.55)$ & \\
\hline LLPTL & & & & $\begin{array}{c}-11.3685^{* * *} \\
(-3.53)\end{array}$ \\
\hline PROF(-1) & $0.0452 * *(2.48)$ & $0.0811 *(2.22)$ & $0.0633 *(2.26)$ & $-0.0042(-0.83)$ \\
\hline SIZE & $0.3658 * *(1.87)$ & $0.4342(1.27)$ & $0.2138(1.29)$ & $0.2573 *(1.84)$ \\
\hline OFBSTA & $-0.411(-0.85)$ & $1.0962 *(1.56)$ & $0.2423(0.79)$ & $-0.0514(-0.92)$ \\
\hline GOVS & $-0.0264 * *(-2.61)$ & $\begin{array}{c}-0.0526 * * * \\
(-3.18) \\
\end{array}$ & $\begin{array}{c}-0.0339 * * * \\
(-3.38) \\
\end{array}$ & $\begin{array}{c}-0.0612^{* *} \\
(-2.51) \\
\end{array}$ \\
\hline $\mathrm{CTI}$ & $-0.00429(-1.42)$ & $-0.0037(-1.45)$ & $-0.0026^{* *}(-2.21)$ & $-0.0039(-1.43)$ \\
\hline FUNDC & $-0.0128(-0.66)$ & $0.0747^{* * *}(2.93)$ & $0.0324(1.13)$ & $-0.0077(-0.93)$ \\
\hline ID & $\begin{array}{c}0.0242^{* * *} \\
(4.18)\end{array}$ & $\begin{array}{c}0.0257^{* * *} \\
(4.13)\end{array}$ & $\begin{array}{c}0.0153^{* * *} \\
(3.88)\end{array}$ & $\begin{array}{c}0.0273^{* * *} \\
(4.15)\end{array}$ \\
\hline INFR & $-0.1252(-1.33)$ & $-0.1193 *(-1.81)$ & $-0.2281 * *(-2.23)$ & $-0.1472 *(-1.81)$ \\
\hline GGDP & $0.5217(0.77)$ & $0.4159(0.87)$ & $0.8160(1.13)$ & $0.6192(0.89)$ \\
\hline CMD & 0.0025 (1.49) & $0.00129 * *(2.28)$ & $0.0016 * *(2.51)$ & $0.0012 *(1.87)$ \\
\hline BSD & $\begin{array}{c}-1.8872 * * * \\
(2.93)\end{array}$ & $\begin{array}{c}-2.3108 * * * \\
(-3.66)\end{array}$ & $\begin{array}{c}-2.0291 * * * \\
(-3.77)\end{array}$ & $\begin{array}{c}-1.6525 * * * \\
(-3.73)\end{array}$ \\
\hline $\mathrm{PCB}$ & $0.5028(0.87)$ & $-0.52921(-1.55)$ & $-0.10213(-0.77)$ & $0.1418(0.92)$ \\
\hline Adjusted $\mathrm{R}^{2}$ & 68.78 & 59.08 & 62.33 & 70.12 \\
\hline $\begin{array}{l}\text { Hausman Test for } \\
\text { Endogeneity, } F(p- \\
\text { value) }\end{array}$ & $19.2634(0.000)$ & $15.6932(0.000)$ & $20.0141(0.000)$ & $19.8493(0.000)$ \\
\hline $\begin{array}{l}\text { White test for } \\
\text { Heteroskedasticity, } \\
\text { p-value }\end{array}$ & 0.000 & 0.000 & 0.000 & 0.000 \\
\hline $\begin{array}{l}\text { Breusch-Godfrey } \\
\text { Serial correlation } \\
\text { LM test, p-value }\end{array}$ & 0.021 & 0.011 & 0.010 & 0.013 \\
\hline $\begin{array}{l}\text { Hausman Test for } \\
\text { Fixed or Random } \\
\text { Effect, } p \text {-value }\end{array}$ & 1.000 & 1.000 & 1.000 & 1.000 \\
\hline Sargantest(p-value) & 0.398 & 0.592 & 0.493 & 0.723 \\
\hline Observations & 320 & 320 & 320 & 320 \\
\hline Number of banks & 38 & 38 & 38 & 38 \\
\hline
\end{tabular}

Notes: The table shows the empirical results from GMM panel estimator. Dependent variable is ROA (performance) for all four models. ${ }^{* * *},{ }^{* *}$ and $*$ indicate significance at the $1 \%, 5 \%$ and $10 \%$ respectively. For Hausman test $p$-values are in parentheses. t-statistics are shown in parentheses. 
Regarding the control variables for capital equation we have got similar results compared to benchmark results except very few exceptions. In terms of control variables used in risk equation, the mostly same results are found in compared with benchmark results. The exceptions are: the coefficient of SIZE is positive. The opposite sign to the benchmark results are also found for CMD, and BSD. Regarding control variables used in profitability equation we find results in same direction compared to the benchmark results. It is found that the model and technique is robust when different alternative measures for capital, risk, profitability and other control variables are used.

\section{Conclusion and Suggestions}

In this study an attempt was made to examine the interrelationship among risk taking, capital regulation and performance by using an unbalanced panel data from 38 banks in Bangladesh for the period 2007 to 2016. We use banks internal control variables and macroeconomic variables to examine the relationships among the risk taking, capital regulations and performance. We apply recent GMM panel data technique to assess the relationships. The empirical results show that there is a significant negative relationship between capital and risk i.e. as capital adequacy ratio increases the risk taken by banks decreases significantly. It is also seen from the study that there is a significant positive relationship between capital regulation and banks' performance which implies that as the capital adequacy ratio increases the performance of banks also increases. There is a significant negative relation between risk and performance which indicates that banks with lower level of risk perform better.

In the existing literature, three simultaneous equations are not used to describe the relationship among risk, capital and performance. The literature does not show the both way causal relationship among these three variables. For example Lee and Hsieh (2013) show only the impact of capital on profitability and risk by using two simultaneous equations. Moreover, there is no comprehensive study on interrelationship among risk, capital regulation and performance. In their study they use equity to total assets as a proxy for capital measure. They ignore to use capital adequacy ratio. To make up this gap we use three simultaneous equations and capital adequacy ratio as a proxy for capital regulation.

In our study we use more banks' important internal control variables as well as significant macroeconomic variables that influencing the relationships among the risk, capital regulation and performance. From our empirical result we see that larger banks have a lower amount of capital adequacy ratio and take lower level of risk. On the other hand, larger banks perform better. Labour efficient banks hold more capital. Inflation has a negative significant impact on capital adequacy and risk and has a significant negative impact on performance. We also see from the result that as capital market develops the capital and performance increase significantly and the risk decreases. As banking sector develops the capital 
adequacy and risk increase, but the performance decreases. This seems significantly because of increasing competition. Private commercial banks hold more capital and take lower risk and that the private commercial banks perform better.

Our empirical results give rise to a number of policy decisions. The main objective of our research is to see whether capital regulation increase performance and decrease risk. In fact this is one of the main objectives of introducing BASEL II in Bangladesh. Our empirical results show that there is a significant negative relationship between capital adequacy and risk. Hence the objective of BASEL II is found to be attained. On the other hand, there is a significant positive relationship between capital adequacy and performance. From the negative relationship between capital adequacy and risk it can be said that the regulatory agency should look after the banks having excessive risky undertakings. Management should take part in decision making regarding the capital adequacy as labour efficient banks hold more capital. Regulator should also monitor the large banks because they hold lower amount of capital adequacy. The government should take measure to control the inflation and to increase the growth in real GGP. The policy makers also need to take measures for the development of capital market. The government should consider the risk and performance when they give permission for the establishment of new banks because it will increase risk and decrease performance of banks. Finally state-owned banks from the economic view point may either be privatized so that capital and performance would increase and risk would decrease or other alternatives may be attempted to overcome the relevant flows so that risk and performance may be efficiently balanced. It is found that the model and technique is robust when different alternative measures for capital, risk, profitability and other control variables are used.

\section{References}

Aggarwal, R., \& Jacques, K. T. (2001). The impact of FDICIA and prompt corrective action on bank capital and risk: Estimates using a simultaneous equations model. Journal of Banking \& Finance, 25(6), 1139-1160. doi: http://dx.doi.org/10.1016/S0378-4266(00)00125-4

Agoraki, M.-E. K., Delis, M. D., \& Pasiouras, F. (2011). Regulations, competition and bank risktaking in transition countries. Journal of Financial Stability, 7(1), 38-48. doi: 10.1016/j.jfs.2009.08.002

Altunbas, Y., Carbo, S., Gardener, E. P. M., \& Molyneux, P. (2007). Examining the Relationships between Capital, Risk and Efficiency in European Banking. European Financial Management, 13(1), 49-70.

Arellano, M., \& Bover, O. (1995). Another look at the instrumental variable estimation of error-components models. Journal of Econometrics, 68(1), 29-51. doi: http://dx.doi.org/10.1016/0304-4076(94)01642-D

Ayuso, J., Pérez, D., \& Saurina, J. (2004). Are capital buffers pro-cyclical?: Evidence from Spanish panel data. Journal of Financial Intermediation, 13(2), 249-264. doi: http://dx.doi.org/10.1016/S1042-9573(03)00044-5 
Relationship between Risk-taking, Capital Regulation and Bank Performance: Empirical ...

Barth, J. R., Caprio, G., \& Levine, R. (2005). Rethinking bank regulation: Till angels govern: Cambridge University Press.

Barth, J. R., Caprio, G., \& Levine, R. (2008). Bank regulations are changing: For better or worse\&quest. Comparative Economic Studies, 50(4), 537-563.

Blum, J. (1999). Do capital adequacy requirements reduce risks in banking? Journal of Banking \& Finance, 23(5), 755-771. doi: http://dx.doi.org/10.1016/S0378-4266(98)00113-7

Blundell, R., \& Bond, S. (2000). GMM Estimation with Persistent Panel Data: an Application to Production Functions. Econometric Reviews, 19(3), 321-340.

Breusch, T. S. (1978). Testing for autocorrelation in dynamic linear models. Australian Economic Papers, 17(31), 334-355.

Calem, P., \& Rob, R. (1999). The Impact of Capital-Based Regulation on Bank Risk-Taking. Journal of Financial Intermediation, 8(4), 317-352. doi: http://dx.doi.org/10.1006/jifin.1999.0276

Ediz, T., Michael, I. M., \& Perraudin, W. (1998). The Impact of Capital Requirements on U.K. Bank Behaviour. FRBNY Economic Policy Review, 15-22.

Eubanks, W. (2010). The status of the Basel III Capital Adequacy Accord, Congressional Research Service, 7-5700: Accessed.

Fiordelisi, F., Marques-Ibanez, D., \& Molyneux, P. (2011). Efficiency and risk in European banking. Journal of Banking \& Finance, 35(5), 1315-1326. doi: 10.1016/j.jbankfin.2010.10.005

Francis, W. B., \& Osborne, M. (2012). Capital requirements and bank behavior in the UK: Are there lessons for international capital standards? Journal of Banking \& Finance, 36(3), 803816. doi: 10.1016/j.jbankfin.2011.09.011

Furlong, F. T., \& Keeley, M. C. (1989). Capital Regulation and Bank Risk-taking: A Note. Journal of Banking \& Finance, 13(6), 883-891.

Goddard, J., Liu, H., Molyneux, P., \& Wilson, J. O. S. (2010). Do Bank Profits Converge? European Financial Management, no-no. doi: 10.1111/j.1468-036X.2010.00578.x

Goddard, J., Molyneux, P., \& Wilson, J. O. (2004). The profitability of european banks: a cross-sectional and dynamic panel analysis. The Manchester School, 72(3), 363-381.

Godfrey, L. G. (1978). Testing against general autoregressive and moving average error models when the regressors include lagged dependent variables. Econometrica: Journal of the Econometric Society, 1293-1301.

Guidara, A., Lai, V. S., Soumaré, I., \& Tchana, F. T. (2013). Banks' capital buffer, risk and performance in the Canadian banking system: Impact of business cycles and regulatory changes. Journal of Banking \& Finance, 37(9), 3373-3387. doi: 10.1016/j.jbankfin.2013.05.012

Ho, S. J., \& Hsu, S.-C. (2010). Leverage, performance and capital adequacy ratio in Taiwan's banking industry. Japan and the World Economy, 22(4), 264-272. doi: 10.1016/j.japwor.2010.06.007

Homölle, S. (2004). Bank capital regulation, asset risk, and subordinated uninsured debt. Journal of Economics and Business, 56(6), 443-468. doi: 10.1016/j.jeconbus.2004.06.002

Hughes, J. P., \& Mester, L. J. (1998). Bank capitalization and cost: evidence of scale economies in risk management and signaling. The Review of Economics and Statistics, 80, 314-325. 
Hussain, M. E., \& Hassan, M. K. (2005). Basel Capital Requirements and Bank Credit Risk Taking In Developing Countries. Department of Economics and Finance Working Papers, 1991-2006. Paper 34.

lannotta, G., Nocera, G., \& Sironi, A. (2007). Ownership structure, risk and performance in the European banking industry. Journal of Banking \& Finance, 31(7), 2127-2149. doi: 10.1016/j.jbankfin.2006.07.013

Iwatsubo, K. (2007). Bank capital shocks and portfolio risk: Evidence from Japan. Japan and the World Economy, 19(2), 166-186. doi: 10.1016/j.japwor.2005.09.001

Jacques, K., \& Nigro, P. (1997). Risk-based capital, portfolio risk, and bank capital: A simultaneous equations approach. Journal of Economics and Business, 49(6), 533-547.

Kahane, Y. (1977). Capital Adequacy and the Regulation of Financial Intermediaries (Vol. 1).

Keeley, M. C., \& Furlong, F. T. (1990). A reexamination of mean-variance analysis of bank capital regulation. Journal of Banking \& Finance, 14(1), 69-84. doi: 10.1016/03784266(90)90036-2

Kim, D., \& Santomero, A. M. (1988). Risk in Banking and Capital Regulation. Journal of Finance, 43, 1219-1233.

Koehn, M., \& Santomero, A. M. (1980). Regulation of Bank Capital and Portfolio Risk. Journal of Finance, 35, 1235-1244.

Kwan, S., \& Eisenbeis, R. A. (1997). Bank Risk, Capitalization, and Operating Efficiency. Journal of Financial Services Research, 12, 117-131.

Laeven, L., \& Levine, R. (2009). Bank governance, regulation and risk taking. Journal of Financial Economics, 93(2), 259-275. doi: 10.1016/j.jfineco.2008.09.003

Lee, C.-C., \& Hsieh, M.-F. (2013). The impact of bank capital on profitability and risk in Asian banking. Journal of International Money and Finance, 32, 251-281. doi: 10.1016/j.jimonfin.2012.04.013

Lee, T.-H., \& Chih, S.-H. (2013). Does financial regulation affect the profit efficiency and risk of banks? Evidence from China's commercial banks. The North American Journal of Economics and Finance, 26, 705-724. doi: 10.1016/j.najef.2013.05.005

Lin, S. L., Penm, J. H. W., Gong, S.-C., \& Chang, C.-S. (2005). Risk-based capital adequacy in assessing on insolvency-risk and financial performances in Taiwan's banking industry. Research in International Business and Finance, 19(1), 111-153. doi: 10.1016/j.ribaf.2004.10.006

Mbizi, R. (2012). An Analysis of the Impact of Minimum Capital Requirements on Commercial Bank Performance in Zimbabwe. International Journal of Independent Research and Studies, 1(4), 124-134.

Naceur, S. B., \& Kandil, M. (2009). The impact of capital requirements on banks' cost of intermediation and performance: The case of Egypt. Journal of Economics and Business, 61(1), 70-89.

Naceur, S. B., \& Omran, M. (2011). The effects of bank regulations, competition, and financial reforms on banks' performance. Emerging Markets Review, 12(1), 1-20. doi: 10.1016/j.ememar.2010.08.002

Nier, E., \& Baumann, U. (2006). Market discipline, disclosure and moral hazard in banking. Journal of Financial Intermediation, 15(3), 332-361. 
Relationship between Risk-taking, Capital Regulation and Bank Performance: Empirical ...

Pasiouras, F., \& Kosmidou, K. (2007). Factors influencing the profitability of domestic and foreign commercial banks in the European Union. Research in International Business and Finance, 21(2), 222-237. doi: 10.1016/j.ribaf.2006.03.007

Rime, B. (2001). Capital requirements and bank behaviour: Empirical evidence for Switzerland. Journal of Banking \& Finance, 25(4), 789-805. doi: http://dx.doi.org/10.1016/S0378-4266(00)00105-9

Scannella, E. (2012). Capital Regulation and Italian Banking System: Theory and Empirical Evidence. International Journal of Economics and Finance, 4(2). doi: 10.5539/ijef.v4n2p31

Shrieves, R. E., \& Dahl, D. (1992). The relationship between risk and capital in commercial banks. Journal of Banking \& Finance, 16(2), 439-457. doi: https://doi.org/10.1016/03784266(92)90024-T

Tan, Y., \& Floros, C. (2013). Risk, capital and efficiency in Chinese banking. Journal of International Financial Markets, Institutions and Money, 26, 378-393. doi: 10.1016/j.intfin.2013.07.009

Tsai, J.-Y., \& Hung, W.-M. (2013). Bank capital regulation in a cap option framework. International Review of Economics \& Finance, 25, 66-74. doi: 10.1016/j.iref.2012.05.002

Vollmer, U., \& Wiese, H. (2013). Minimum capital requirements, bank supervision and special resolution schemes. Consequences for bank risk-taking. Journal of Financial Stability, 9(4), 487-497. doi: 10.1016/j.jfs.2013.07.004

White, H. (1980). A heteroskedasticity-consistent covariance matrix estimator and a direct test for heteroskedasticity. Econometrica: Journal of the Econometric Society, 817-838.

Zhang, J., Jiang, C., Qu, B., \& Wang, P. (2013). Market concentration, risk-taking, and bank performance: Evidence from emerging economies. International Review of Financial Analysis, 30, 149-157. doi: 10.1016/j.irfa.2013.07.016

Zhang, Z.-y., Wu, J., \& Liu, Q.-f. (2008). Impacts of Capital Adequacy Regulation on Risktaking Behaviors of Banking. Systems Engineering - Theory \& Practice, 28(8), 183-189. doi: http://dx.doi.org/10.1016/S1874-8651(09)60035-1 
Mohammad Morshedur RAHMAN, Ali Arshad CHOWDHURY \& Mouri DEY

\section{Appendix}

Table A1. Robustness

\begin{tabular}{|c|c|c|c|c|c|c|}
\hline & Model 13 & Model 14 & Model 15 & Model 16 & Model 17 & Model 18 \\
\hline Variables & RISK=LLPNPL & $\begin{array}{l}\text { RISK=ZSCOR } \\
\text { E }\end{array}$ & RISK=LLPNPL & RISK=ZSCORE & RISK=LLPNPL & RISK=ZSCORE \\
\hline C & $\begin{array}{l}-7.001 \\
(-0.75) \\
\end{array}$ & $\begin{array}{l}-5.211 \\
(-0.87) \\
\end{array}$ & $\begin{array}{l}0.4321 * * * \\
(2.78) \\
\end{array}$ & $\begin{array}{l}0.7812^{* *} \\
(2.09)\end{array}$ & $\begin{array}{l}-3.456 \\
(-0.88) \\
\end{array}$ & $\begin{array}{l}-4.5623 \\
(-0.88) \\
\end{array}$ \\
\hline EQUITY & & & $\begin{array}{l}5.2036 \\
(1.40)\end{array}$ & $\begin{array}{l}2.3162 * * *(6 \\
.26)\end{array}$ & $\begin{array}{l}0.1923^{* * *} \\
(3.45)\end{array}$ & $\begin{array}{l}0.1069 * * * \\
(3.29)\end{array}$ \\
\hline LLPNPL & $\begin{array}{l}0.0103^{*} \\
(1.77)\end{array}$ & & & & $\begin{array}{l}-0.0273^{*} \\
(-1.78)\end{array}$ & \\
\hline ZSCORE & & $\begin{array}{l}0.0654^{*} \\
(1.72) \\
\end{array}$ & & & & $\begin{array}{l}-0.0057^{*} \\
(-1.84) \\
\end{array}$ \\
\hline ROE & $\begin{array}{l}0.7723 \\
(1.02) \\
\end{array}$ & $\begin{array}{l}0.3423 \\
(1.43) \\
\end{array}$ & $\begin{array}{l}1.7775 \\
(0.59)\end{array}$ & $\begin{array}{l}1.9623^{* * *} \\
(5.73)\end{array}$ & & \\
\hline LLPNPL(-1) & & & $\begin{array}{l}0.6684 * * * \\
(12.13) \\
\end{array}$ & & & \\
\hline ZSCORE(-1) & & & & $\begin{array}{l}0.7999 * * * \\
(47.99)\end{array}$ & & \\
\hline $\operatorname{ROE}(-1)$ & & & & & $\begin{array}{l}0.0324^{* *} \\
(2.29) \\
\end{array}$ & $\begin{array}{l}0.0712^{* *} \\
(2.17)\end{array}$ \\
\hline SIZE & $\begin{array}{l}-0.8662^{* *} \\
(-2.49) \\
\end{array}$ & $\begin{array}{l}-0.6624^{* * *} \\
(-3.31) \\
\end{array}$ & $1.0424(0.55)$ & $\begin{array}{l}0.3831^{*} \\
(1.77)\end{array}$ & $\begin{array}{l}0.2031 \\
(0.89) \\
\end{array}$ & $\begin{array}{l}0.1048 \\
(0.78) \\
\end{array}$ \\
\hline LABOUR & $\begin{array}{l}0.03432 * * *( \\
5.58)\end{array}$ & $\begin{array}{l}0.422^{* * *} \\
(5.42)\end{array}$ & & & & \\
\hline RWATA & $\begin{array}{l}-1.8734 \\
(-0.44) \\
\end{array}$ & $\begin{array}{l}-0.0552 \\
(-1.33) \\
\end{array}$ & & & & \\
\hline TLTA & $\begin{array}{l}-0.8756 \\
(-0.35) \\
\end{array}$ & $\begin{array}{l}-0.9321 \\
(-0.68) \\
\end{array}$ & & & & \\
\hline OFBSTA & & & & & $\begin{array}{l}-0.0742 \\
(-0.64) \\
\end{array}$ & $\begin{array}{l}-0.0674 \\
(-0.23) \\
\end{array}$ \\
\hline GOVS & & & $\begin{array}{l}0.04213^{* *} \\
(2.35)\end{array}$ & $\begin{array}{l}0.0024 \\
(.02)\end{array}$ & $\begin{array}{l}-0.0231^{* *} \\
(-2.54)\end{array}$ & $\begin{array}{l}-0.0253^{* *} \\
(-2.77)\end{array}$ \\
\hline LIQUIDITY & & & $\begin{array}{l}-0.9056^{* *} \\
(-2.25)\end{array}$ & $\begin{array}{l}-0.4532^{*} \\
(-1.68)\end{array}$ & $\begin{array}{l}0.0293^{* *} \\
(2.18)\end{array}$ & $\begin{array}{l}0.0159 * * \\
(2.09)\end{array}$ \\
\hline $\mathrm{CTI}$ & & & & & $\begin{array}{l}-0.0512 * * * \\
(-2.80)\end{array}$ & $\begin{array}{l}-0.0134 * * * \\
(-2.70)\end{array}$ \\
\hline FUNDC & & & & & $\begin{array}{l}-0.0127 * * * \\
(-2.66)\end{array}$ & $\begin{array}{l}-0.0134^{* * *} \\
(-2.70)\end{array}$ \\
\hline ID & & & & & $\begin{array}{l}0.0082 \\
(1.33) \\
\end{array}$ & $\begin{array}{l}0.0091 \\
(1.21) \\
\end{array}$ \\
\hline INFR & $\begin{array}{l}-0.3212 \\
(-1.16)\end{array}$ & $\begin{array}{l}-0.1924^{*} \\
(-1.81)\end{array}$ & $\begin{array}{l}1.4017 \\
(1.28)\end{array}$ & $\begin{array}{l}-0.5218^{* * *} \\
(-4.60)\end{array}$ & $\begin{array}{l}-0.2358^{* * *} \\
(-3.56)\end{array}$ & $\begin{array}{l}-0.1953^{* * *} \\
(-3.36)\end{array}$ \\
\hline GGDP & $\begin{array}{l}0.1342 \\
(0.34)\end{array}$ & $0.1332(0.43)$ & $\begin{array}{l}-9.1986 * * \\
(-2.30)\end{array}$ & $\begin{array}{l}1.6999 * * * \\
(4.02)\end{array}$ & $0.231(0.78)$ & $\begin{array}{l}0.1692 \\
(0.63)\end{array}$ \\
\hline CMD & $\begin{array}{l}8.4532 * \\
(1.61)\end{array}$ & $\begin{array}{l}5.1242^{* *} \\
(1.99)\end{array}$ & $\begin{array}{l}-0.0675^{* *} \\
(-2.58)\end{array}$ & $\begin{array}{l}-0.0782^{* *} \\
(-2.62)\end{array}$ & $\begin{array}{l}0.0657^{*} \\
(1.91)\end{array}$ & $\begin{array}{l}0.0675^{*} \\
(1.82)\end{array}$ \\
\hline
\end{tabular}


Relationship between Risk-taking, Capital Regulation and Bank Performance: Empirical ...

Table A1 (Cont.)

\begin{tabular}{|c|c|c|c|c|c|c|}
\hline & Model 13 & Model 14 & Model 15 & Model 16 & Model 17 & Model 18 \\
\hline Variables & RISK=LLPNPL & $\begin{array}{l}\text { RISK=ZSCOR } \\
\mathrm{E}\end{array}$ & RISK=LLPNPL & RISK=ZSCORE & RISK=LLPNPL & RISK=ZSCORE \\
\hline BSD & $\begin{array}{l}13.342^{* *} \\
(2.09)\end{array}$ & $\begin{array}{l}11.1870^{*} \\
(1.58)\end{array}$ & $\begin{array}{l}0.08745^{* * * *} \\
(2.77)\end{array}$ & $\begin{array}{l}0.07612^{* * *}( \\
2.82)\end{array}$ & $\begin{array}{l}-1.2745^{* * *} \\
(-3.34)\end{array}$ & $\begin{array}{l}-1.8171^{* * *} \\
(-3.18)\end{array}$ \\
\hline PCB & $\begin{array}{l}\text { 1.324* } \\
(1.70)\end{array}$ & $\begin{array}{l}1.2431^{* *} \\
(2.42)\end{array}$ & $\begin{array}{l}-0.097^{* * *} \\
(-7.16)\end{array}$ & $\begin{array}{l}-0.088^{* * *} \\
(-5.23)\end{array}$ & $\begin{array}{l}0.6241^{* *} \\
(1.79)\end{array}$ & $\begin{array}{l}0.5229 * * \\
(1.98)\end{array}$ \\
\hline Adjusted $\mathrm{R}^{2}$ & 53.94 & 60.33 & 58.35 & 64.17 & 62.97 & 70.13 \\
\hline $\begin{array}{l}\text { Hausman } \\
\text { Test for } \\
\text { Endogeneity } \\
\text { F(p-value) }\end{array}$ & $\begin{array}{l}16.9926 \\
(0.000)\end{array}$ & $\begin{array}{l}17.2369 \\
(0.000)\end{array}$ & $\begin{array}{l}17.0630 \\
(0.000)\end{array}$ & $\begin{array}{l}16.9847 \\
(0.000)\end{array}$ & $\begin{array}{l}17.0630 \\
(0.000)\end{array}$ & $\begin{array}{c}16.9847 \\
(0.000)\end{array}$ \\
\hline $\begin{array}{l}\text { White test } \\
\text { for } \\
\text { Heterosked } \\
\text { asticity, p- } \\
\text { value }\end{array}$ & 0.000 & 0.000 & 0.000 & 0.000 & 0.000 & 0.000 \\
\hline $\begin{array}{l}\text { Breusch- } \\
\text { Godfrey } \\
\text { Serial } \\
\text { correlation } \\
\text { LM test, p- } \\
\text { value }\end{array}$ & 0.026 & 0.013 & 0.011 & 0.012 & 0.011 & 0.012 \\
\hline $\begin{array}{l}\text { Hausman } \\
\text { Test for } \\
\text { Fixed or } \\
\text { Random } \\
\text { Effect, p- } \\
\text { value }\end{array}$ & 1.000 & 1.000 & 1.000 & 1.000 & 1.000 & 1.000 \\
\hline $\begin{array}{l}\text { Sargan test } \\
\text { (p-value) }\end{array}$ & 0.555 & 0.711 & 0.581 & 0.544 & 0.581 & 0.544 \\
\hline $\begin{array}{l}\text { Observation } \\
\mathrm{s}\end{array}$ & 320 & 320 & 320 & 320 & 320 & 320 \\
\hline $\begin{array}{l}\text { Number of } \\
\text { banks }\end{array}$ & 38 & 38 & 38 & 38 & 38 & 38 \\
\hline
\end{tabular}

Notes: The table shows the empirical results from GMM panel estimator. Dependent variable is ROA (performance) for all four models. ${ }^{* *}, * *$ and $*$ indicate significance at the $1 \%, 5 \%$ and $10 \%$ respectively. For Hausman test $\mathrm{p}$-values are in parentheses. $\mathrm{t}$-statistics are shown in parentheses. 